\title{
TITLE:
}

\section{ON MEGABALANUS (CIRRIPEDIA, THORACICA) OF JAPAN}

$\operatorname{AUTHOR}(S):$

Yamaguchi, Toshiyuki

\section{CITATION:}

Yamaguchi, Toshiyuki. ON MEGABALANUS (CIRRIPEDIA, THORACICA) OF JAPAN. PUBLICATIONS OF THE SETO MARINE BIOLOGICAL LABORATORY 1973, 21(2): 115-140

ISSUE DATE:

1973-03-31

URL:

http://hdl.handle.net/2433/175804

RIGHT: 


\title{
ON MEGABALANUS (CIRRIPEDIA, THORACICA) OF JAPAN 1 )
}

\author{
Toshiyuki YAMAGUCHI \\ Geological Institute, University of Tokyo, Tokyo, Japan
}

With Text-figures $1-11$ and Plates VI-VIII

\section{Introduction}

In 1916, Pilsbry described two new subspecies of Balanus (Megabalanus) tintinnabulum (Linné) from Japan. Since then specimens of Megabalanus found along the Japanese coast have been called either $B$. (M.) tintinnabulum rosa Pilsbry or $B$. (M.) tintinnabulum volcano Pilsbry by most authors including Broch (1922), Hiro (1932, 1937 \& 1939b), Krüger (1911), Nilsson-Cantell (1927 \& 1932), Tarasov \& Zevina (1957) and Utinomi $(1949,1955,1958,1962,1966 \& 1970)$. These two subspecies are similar, but the morphological differences are clearly recognizable. Increasing knowledge of the distribution, habitat, breeding season etc. of Japanese Megabalanus offers the opportunity to reevaluate the morphological differences and to again attempt to determine whether they are of intraspecific or interspecific significance. In this paper the writer emphasizes that qualitative and numerical treatment of morphology alone does not offer any definite information for the taxonomic identifications of Megabalanus. However, field evidence shows clearly that the differences between the two Megabalanus of Japan are enough to require their assignment to separate species.

\section{Materials}

Most of the recent specimens used for morphological study were collected from Tanabe Bay (Loc. 5). Additional materials for comparative study were obtained from many localities scattered along the Japanese coast which are listed as follows:

Loc. 1.-Balanus (Megabalanus) rosa: Hiraiga, Tanohata-mura, Shimohei-gun, Iwate Pref. (39 $56^{\prime} \mathrm{N}^{\text {, }}$ 141 $56.5^{\prime}$ E.). Attached on buoys. Collector: Y. Iwasaki.

Loc. 2a,b.--B. (M.) volcano and B. (M.) rosa: Aburatsubo, Miura Gity, Kanagawa Pref. ( $35^{\circ} 9.5^{\prime}$ N., $139^{\circ} 36.5^{\prime}$ E.), 1. volcano: $500 \mathrm{~m} \mathrm{SE}$ of the Aburatsubo Biological Station of the Univ. of Tokyo., b. rosa: $500 \mathrm{~m}$ off the Aburatsubo Biological Station. Attached on buoys.

Loc. 3.-B. (M.) volcano: Akane Is., Shimoda, Kamo-gun, Shizuoka Pref. (3439.5' N., $138^{\circ} 57^{\prime}$ E.). Loc. 4.-B. (M.) volcano and B. (M.) rosa: Heta, Tagata-gun, Shizuoka Pref. (34⒌5' N., 138 $46^{\prime}$ E.). Attached on buoys.

Loc. 5a-m.-B. (M.) volcano and B. (M.) rosa: Tanabe Bay (Text-fig. 6), near Shirahama, Nishimurogun, Wakayama Pref. $\left(33^{\circ} 42.5^{\prime}\right.$ N., $135^{\circ} 21.5^{\prime}$ E.). a. Takashima Is., b. Shisojima Is., c. Tôshima

1) Contributions from the Seto Marine Biological Laboratory, No. 583.

Publ. Seto Mar. Biol. Lab., XXI (2), 115-140, $1973 . \quad$ (Article 13) 
Is., d. Pier of the Seto Marine Biological Laboratory of Kyoto Univ., e. Tower for oceanic research (T.O.R.), f. Hatakejima Is., g. Hosonoura (Attached on buoys), h. Northwestern headland of Ikeda, i. Kashima Is., j. Utinoura Bay (Attached on buoys), k. Northwestern headland of Takinai, l. Hatashima Is., m. Tanabe (Attached on concrete-reef).

Loc. 6.-B. (M.) rosa: Pier of the Marine Biological Laboratory of Kobe Univ., Tanoshiro, Iwaya

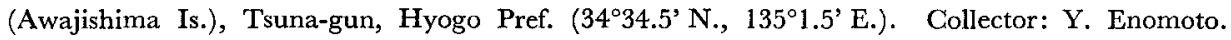

Loc. 7.-B. (M.) volcano and B. (M.) rosa: Tosa Bay off Namura-Nishinohama, Aki City, Kochi Pref. $\left(33^{\circ} 27.5^{\prime}\right.$ N., $133^{\circ} 56.5^{\prime}$ E.). Attached on buoys. Collector: Y. Iwasaki.

Loc. 8.-B. (M.) volcano and B. (M.) rosa: Aoshima Is., Miyazaki City, Miyazaki Pref. (31 $48.5^{\prime}$ N., $131^{\circ} 28.5^{\prime}$ E. $)$.

Loc. 9.-B. (M.) volcano: Ishidera, Nishinoomote Gity (Tanegashima Is.), Kagoshima Pref. (32² $42.5^{\prime}$ N., $130^{\circ} 58.5$ ' E.).

Loc. 10.-B. (M.) volcano: Danjo Isls. (East China Sea), Fukue City, Nagasaki Pref. (32 $00^{\prime}$ N., $128^{\circ}$

23' E.). Collector: K. Matsubayashi (Specimens are preserved in the Seto Marine Biological Laboratory).

Loc. 11.-B. (M.) rosa: $1.5 \mathrm{Km}$ north of the Amakusa Marine Biological Laboratory of Kyushu Univ., Tomioka, Amakusa-gun, Kumamoto Pref. (32³2.5’ N., $130^{\circ} 2^{\prime}$ E.).

\section{Morphological Differences}

Most of the field observations were made along the shores of Tanabe Bay (Loc. 5), Aburatsubo (Loc. 2), Heta (Loc. 4) and Aoshima Is. (Loc. 8). Among many morphological characters which have been used to distinguish Balanus (Megabalanus) volcano and $B$. (M.) rosa, the following are especially noticeable:

1. Color of Wall

The wall of volcano is reddish purple to faint purple in color. But rosa has a yellowish red to reddish purple wall except for a white form. Color of the radii is fainter than that of parietes in volcano, while it is darker than that of parietes in rosa.

2. Surface of Wall

The wall of volcano often has a rough surface with projecting spines (Pl. VI, figs. 2a, b \& 4), while rosa has a smooth wall surface (Pl. VI, figs. la, b, 3, 6 \& 7).

3. Opergular Valve

a) Growth ridge of scutum

The growth ridge of the scutum is weak in volcano (P1. VI, figs. 2c \& e), while it is prominent in rosa (Pl. VI, figs. Ic \& e). The growth ridge is nearly straight, or slightly concave at the center in volcano, while that of rosa is in general concave near the occludent side and slightly convex near the tergal side forming an elongate sshaped ridge.

b) Width of spur of tergum (Text-fig. 1)

Spur of volcano is narrow. Width of the spur (W) ranges from approximately half to one-third of the distance (D) between the anterior side of the spur and the basiscutal angle. However, width of the spur (W) is wider in rosa and is nearly equal to the distance (D) between the anterior side of the spur and the basiscutal angle.

4. CIRRI (Text-figs. 2 and 3)

The most prominent difference between the two species is found in the number 
of segments in the exopodite of cirrus I and in both rami of cirrus III.

5. Mandible (Text-figs. 10 and 11 , Pl. VII, figs. 1a-4b)

In volcano the first to fouth teeth of mandible are large and the fifth and sixth teeth of mandible are minute and sharply pointed; whereas rosa has large first to fourth teeth, and minute but bluntly rounded fifth and sixth teeth.

These morphological differences empirically detected by using such modern techniques of morphological analysis as scanning electron microscope may already justify the conclusion that volcano and rosa are different species, but they probably are still not enough to overcome the widely disseminated opinion that these are subspecies. The logical next step is to refine these qualitative morphological differences into quantitative terms. The width of the spur of the tergum and the number of segments in cirri are thus taken up for statistical analysis in the following section.

\section{Quantitative Analysis of Some Morphological Characters}

1. Statistical Evaluation of Width of Spur

Samples for statistical analysis were collected from Tanabe Bay (Loc. 5) and from Tosa Bay (Loc. 7). At the former area, 24 individuals of $B .(M$.) volcano were collected from the rocky shore in the lower part of the littoral zone of Loc. 5c. They
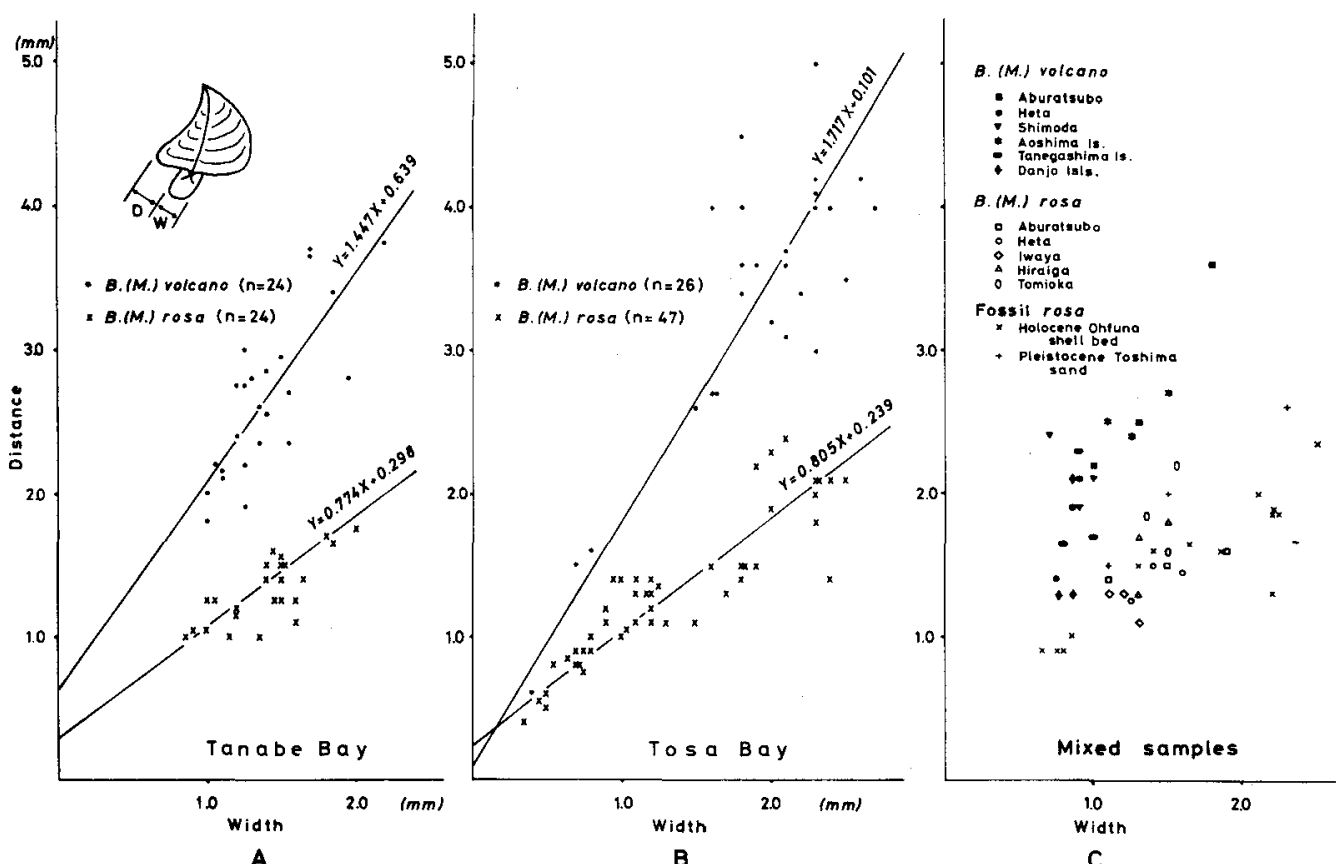

Text-fig. 1. Relation of width of spur (W) and distance (D) between anterior side of spur and basiscutal angle in right tergum. Lines are the reduced major axes for $W$ and $D$. A: B. (M.) volcano and B. (M.) rosa from Tanabe Bay (Loc. 5). B: B. (M.) volcano and $B .(M$.) rosa from Tosa Bay (Loc. 7), C: mixed samples from various localities. 
range from $17.5 \mathrm{~mm}$ to $36.5 \mathrm{~mm}$ in rostro-carinal diameter. 24 individuals of $B .(M$.) rosa were collected from the (submerged) concrete-reef in the lower part of the littoral zone of Loc. $5 \mathrm{~m}$ and range from $14.5 \mathrm{~mm}$ to $26.5 \mathrm{~mm}$ in rostro-carinal diameter. Samples of both species were collected carefully to represent the original population. The specimens from Loc. 7 consist of 26 individuals of volcano and 47 individuals of rosa. Both species were found attached one upon another on the buoys. The rostrocarinal diameter of rosa consists of individuals of various sizes ranging from $9 \mathrm{~mm}$ to $45 \mathrm{~mm}$. The observed range of the rostro-carinal diameter of volcano is approximately same as that of rosa, but volcano has more larger individuals.

The values of width of the spur (W) and distance (D) between the anterior side of the spur and the basiscutal angle in tergum were measured. Right terga of opercular valves were used. The reduced major axis for $\mathrm{W}$ and $\mathrm{D}$ was calculated for each species.

The formula $\mathrm{D}=1.447 \mathrm{~W}+0.639$ is the reduced major axis for volcano, and $\mathrm{D}=0.774 \mathrm{~W}+0.298$ is for rosa both from Loc. 5 (Text-fig. 1A).

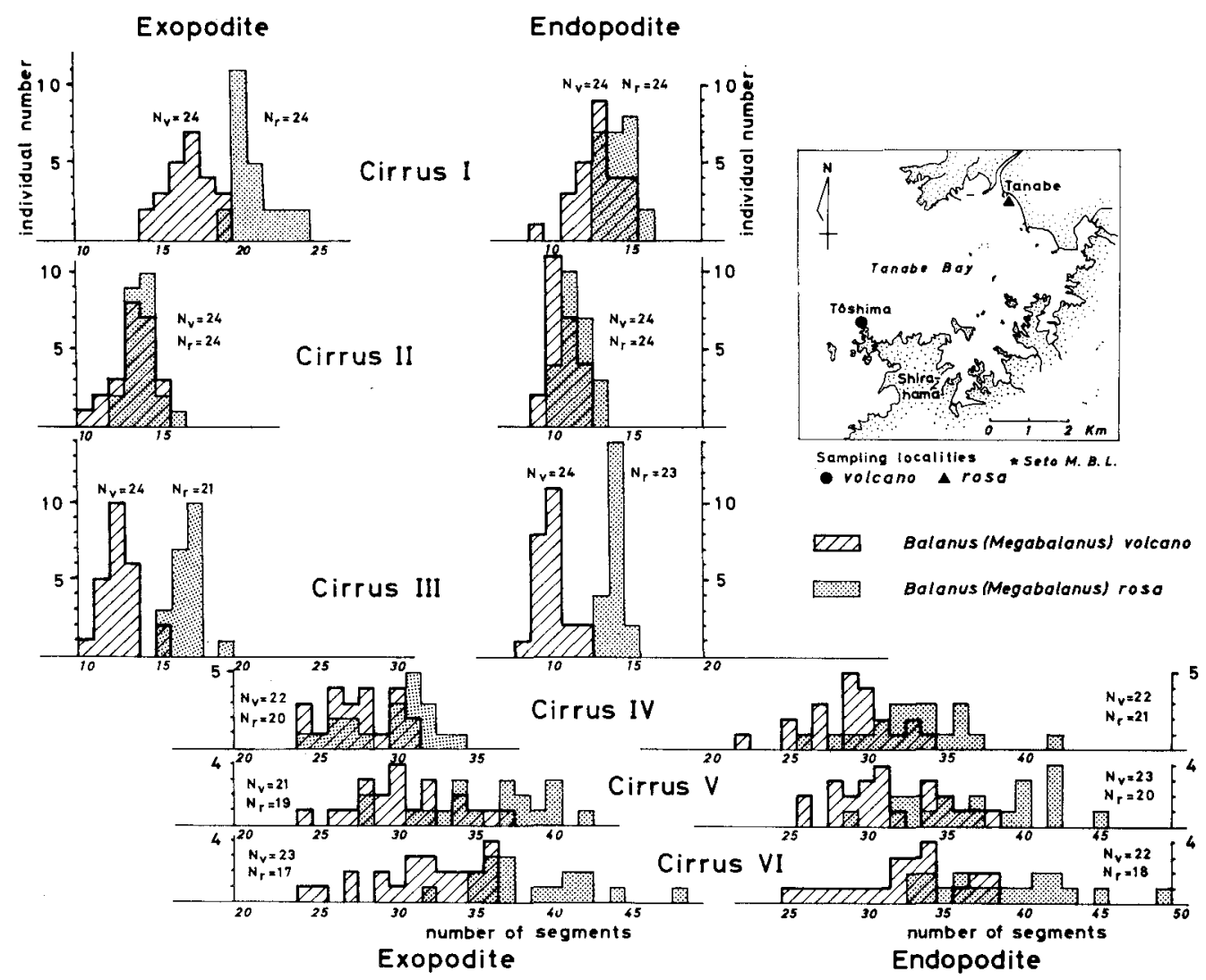

Text-fig. 2. Frequency distribution of number of segments in each right cirrus of $B .(M$.) volcano and $B .(M$.$) rosa from Tanabe Bay (Loc. 5). Nv: Number of individuals of$ $B$. $(M$.) volcano examined. $\mathrm{Nr}$ : Number of individuals of $B$. (M.) rosa examined. 
The formula $\mathrm{D}=1.717 \mathrm{~W}+0.101$ is the reduced major axis for volcano, and $\mathrm{D}=$ $0.805 \mathrm{~W}+0.239$ is the reduced major axis for rosa both from Loc. 7 (Text-fig. 1B).

In comparing figures $A$ and $B$ of text-figure 1, it is clear that the lines for samples of volcano from the two localities are closely similar in slope and position and are clearly different from those of rosa. For reference, mixed samples from various localities are shown in figure $\mathrm{C}$ of text-figure 1. Again the two groups are clearly distinguishable.

2. Number of Segments in Each Girrus

The specimens examined were from Loc. 5 and are the same as those used for statistical analysis of the width of the spur. Samples are composed of 24 individuals of each species. The samples were dissected, and the number of segments of the right cirri were counted. Cirri which lacked some segments or were regenerating after loss of segments were eliminated from the counting.

Generally in all right cirri from cirri I to VI, numbers of segments were larger in rosa than in volcano (Text-fig. 2).

The observed range of the numbers of segments is narrow in both rami of cirri

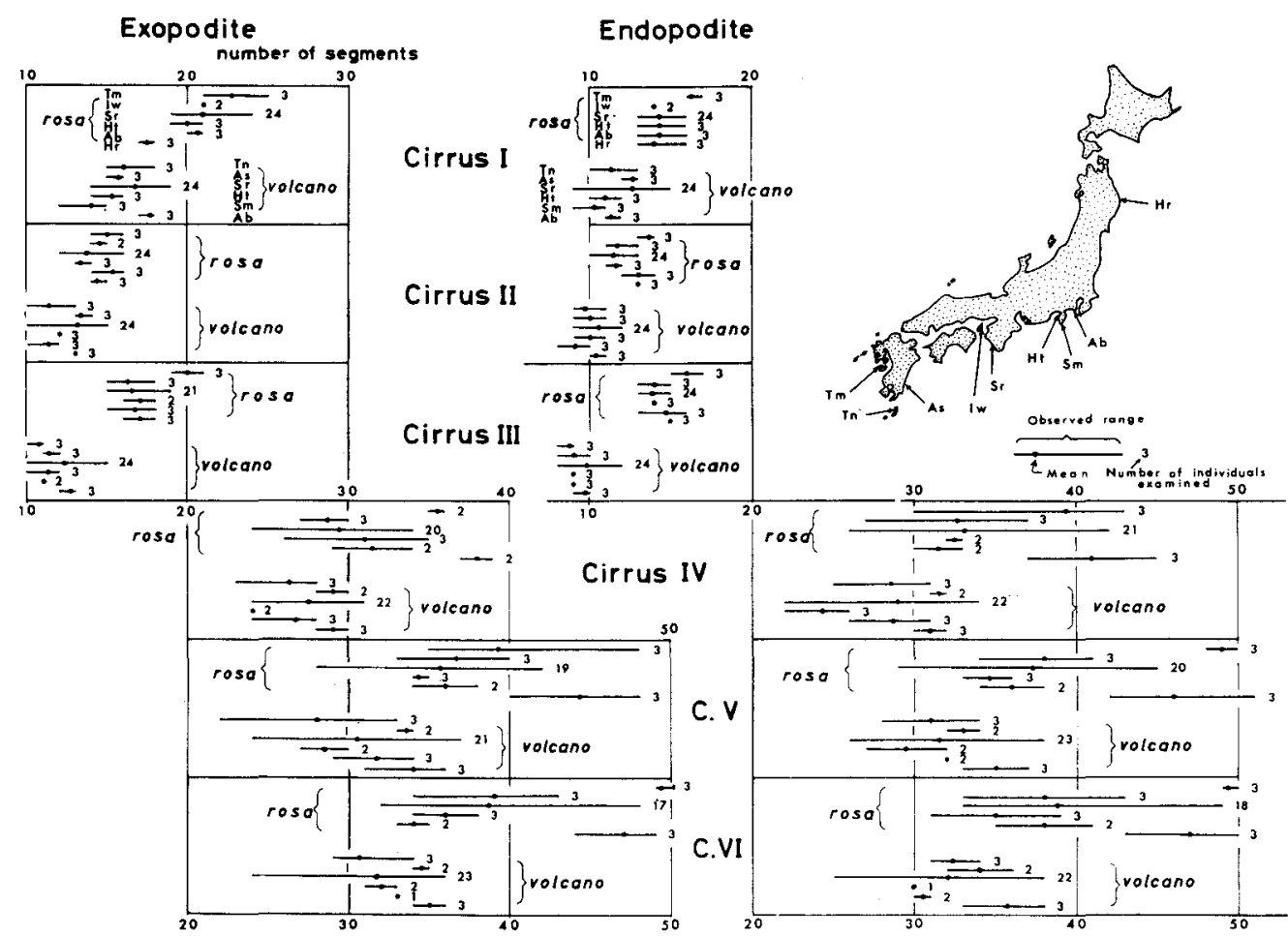

Text-fig. 3. Observed ranges and means of the number of segments in each right cirrus of $B$. (M.) volcano and $B$. (M.) rosa from various localities. $\mathrm{Hr}$ : Hiraiga (Loc. 1), $\mathrm{Ab}$ : Aburatsubo (Loc. 2), Sm: Shimoda (Loc. 3), Ht: Heta (Loc. 4), Sr: Tanabe Bay (Loc. 5), Iw: Iwaya (Loc. 6), As: Aoshima Is. (Loc. 8), Tn: Tanegashima Is. (Loc. 9) and Tm: Tomioka (Loc. 11). 
I to III in contrast with the range observed in cirri IV to VI (Text-fig. 2). The ranges of the numbers of segments in the exopodite of cirrus $I$ and in both rami of cirrus III are distinctly different between the two species, whereas in the endopodite of cirrus I and in both rami of cirrus II, the ranges overlap widely and it is impossible to distinguish the two species by the number of segments alone. In cirri IV to VI, the observed ranges of numbers of segments in both forms also overlap widely demonstrating the impossibility of separation of these two species by this character.

In order to examine further the geographic variation of the taxonomic characters which seemed to be of use in distinguishing volcano and rosa, specimens from various localities along the Japanese coast were dissected. $B$. (M.) rosa was collected at 6 localities: $1(\mathrm{Hr}), 2 \mathrm{a}(\mathrm{Ab}), 4(\mathrm{Ht}), 5 \mathrm{~m}(\mathrm{Sr}), 6(\mathrm{Iw})$, and $11(\mathrm{Tm}) . \quad B .(M$.$) volcano$ was also collected at 6 localities: 2b (Ab), $3(\mathrm{Sm}), 4(\mathrm{Ht}), 5 \mathrm{c}(\mathrm{Sr}), 8(\mathrm{As})$, and 9

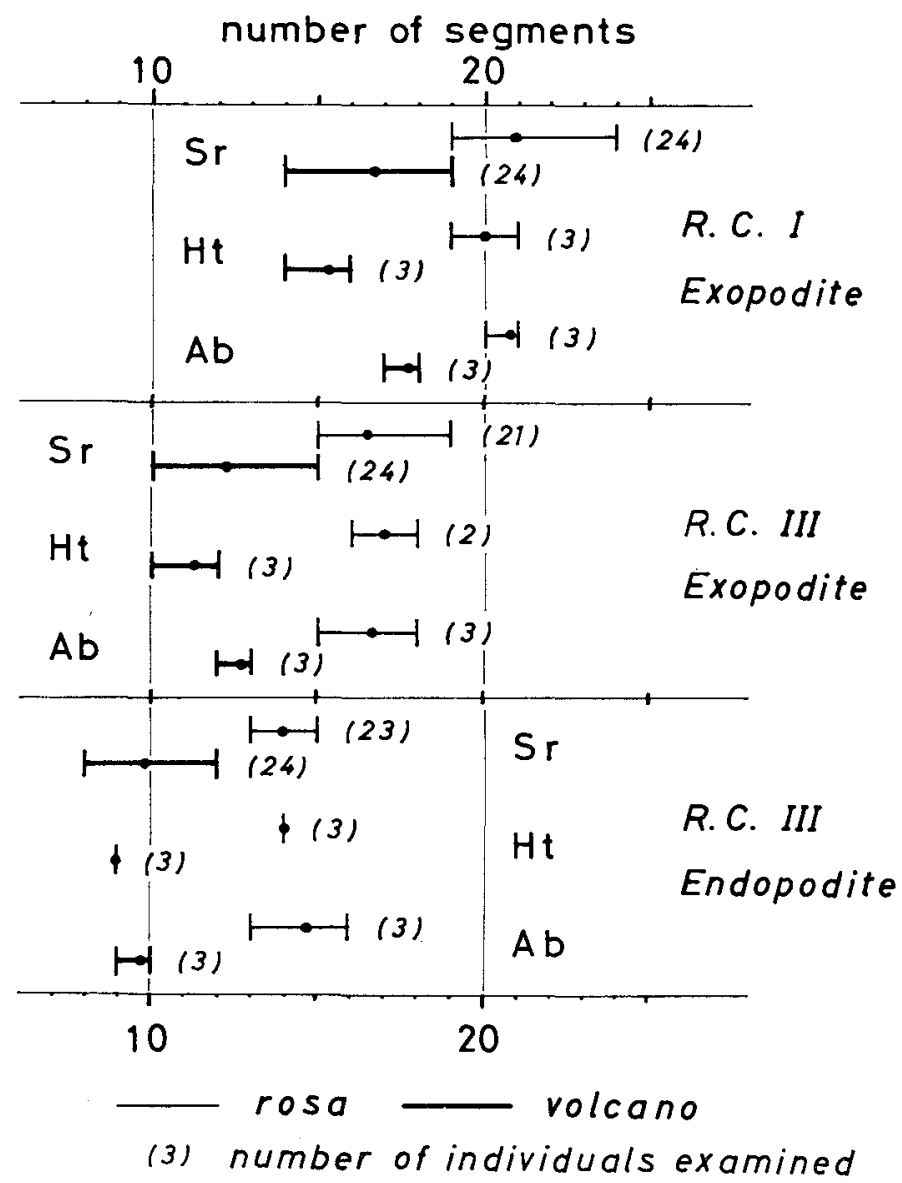

Text-fig. 4. Observed ranges and means of the number of segments in each right cirrus of sympatric $B$. (M.) volcano and $B$. (M.) rosa from Tanabe Bay (Sr. Loc. 5), Heta (Ht, Loc. 4) and Aburatsubo (Ab, Loc. 2). 
(Tn) (Text-fig. 3).

For each species 39 individuals from six localities were dissected. From Loc. 5 (Sr) 24 individuals were dissected, and three specimens from each of the other five localities were dissected. The observed ranges and means of the numbers of segments in cirri I to VI are shown in text-figure 3.

Here again the difference between the number of segments in exopodite of cirrus I and in both rami of cirrus III for volcano and rosa is distinct for all the six localities. The distinction seems to be largest between the specimens from Locs. 2, 4, and 5, where the two species occur together (Text-fig. 4).

\section{Isozymes of $B$. (M.) volcano and $B$. (M.) rosa}

To determine the difference in the contained proteins (particularly isozymes) in living tissues of volcano and rosa, three kinds of isozymes ( $\mathrm{LDH}, \mathrm{MDH}$, Esterases) of these two species were examined by gel electrophoresis. In total 16 individuals, including individuals of volcano from Tôshima Is. (Loc. 5c), and six individuals of rosa from Hatakejima Is. (Loc. 5f), and two individuals of rosa from Tanabe (Loc. 5m), were collected in October, 1972, and examined after about a week of laboratory cultivation.

Four internal tissues were examined: muscles $(\mathrm{Mu})$ including depressor muscle and adductor muscle; tissues of internal organ (I) including gizzard, intenstine (stomach-intenstine) and testis; ovary $(\mathrm{O})$; and opercular membrane (Me). This was done in consideration of the distribution of isozymes in various tissues. Tissues were homogenized in an equivalent volume of distilled water, and centrifuged at $20,000 \mathrm{~g}$ for 20 minutes. The clear supernatants thus obtained were subjected to horizontal starch gel electrophoresis in Tris-EDTA-boric acid buffer systems $(\mathrm{pH}$ 8.7) as discribed by Kraus and Neely (1964) at constant current of $4.8 \mathrm{~mA}$ per $\mathrm{cm}^{2}$ for about three hours, until amido black $10 \mathrm{~B}$ marker migrated to $8 \mathrm{~cm}$.

The activity of isozymes was extremely weak. All isozymes were detected on the anordal side of the start line. Tetrazolium oxidase (TO) of volcano and rosa migrated to the same places on the gels.

Lactate dehydrogenases (LDH). Very weak activity is detected as a single faint band.

Malate dehydrogenases (MDH). In volcano, the distribution pattern of $\mathrm{MDH}$ appears invariably in three bands (MDH 1, 2 and 3), some difference in the staining intensity of the isozymes bands was found among organs as well as individuals. Textfig. 5A. shows the dominant pattern of gradation. In dominant MDH pattern of gradation in muscle $(\mathrm{Mu}), \mathrm{MDH} 1$ is a strong band, MDH 2 is moderate, and $\mathrm{MDH}$ 3 is weak. However, in tissues of internal organ (I), reverse gradation is observed. In the opercular membrane (Me), MDH 2 is a dark band, MDH 1 is intermediate, and MDH 3 is light. The MDH pattern of rosa also shows no variation in electrophoretic mobility, and consists of three bands, i.e., an intermediate band of MDH 3, a strong band of MDH 4 and a weak band of MDH 5. MDH 5 appears on the 
cathordal side of the TO band. This gradation pattern is constant throughout all the tissues examined. MDH 3 is found in both volcano and rosa. $\mathrm{MDH} 1$ and 2 are isozymes specific to volcano, and $\mathrm{MDH} 4$ and 5 are isozymes specific to rosa.

Esterases (Text-fig. 5B). On the extracts of muscle, tissues of internal organ, ovary and opecular membrane of volcano and rosa appear as 13 bands. Esterases 3, 4 and 5 are found in both species. Esterases 1, 7, 8 and 11 are found only in volcano; esterases 2, 6, 9, 10, 12 and 13 are found only in rosa.

Major Protein. On extracts of muscle of both volcano and rosa, appears as a single band.

\section{Distribution}

The distribution of the two species of Megabalanus based on newly obtained and previous information is summarized in text-figure 6 . The northern limit of distribution of $B$. (M.) volcano is Sagami Bay on the Pacific side, and Awashima Island near Sakata on the Japan Sea side. The distribution extends southward to the Yaeyama Islands near Formosa. $B .(M$.) rosa lives everywhere along the Japanese coast, from southern Sakhalin southward to the Yaeyama Islands. The distribution of these two species overlaps largely in central and southern Japan. In fact, both species are found

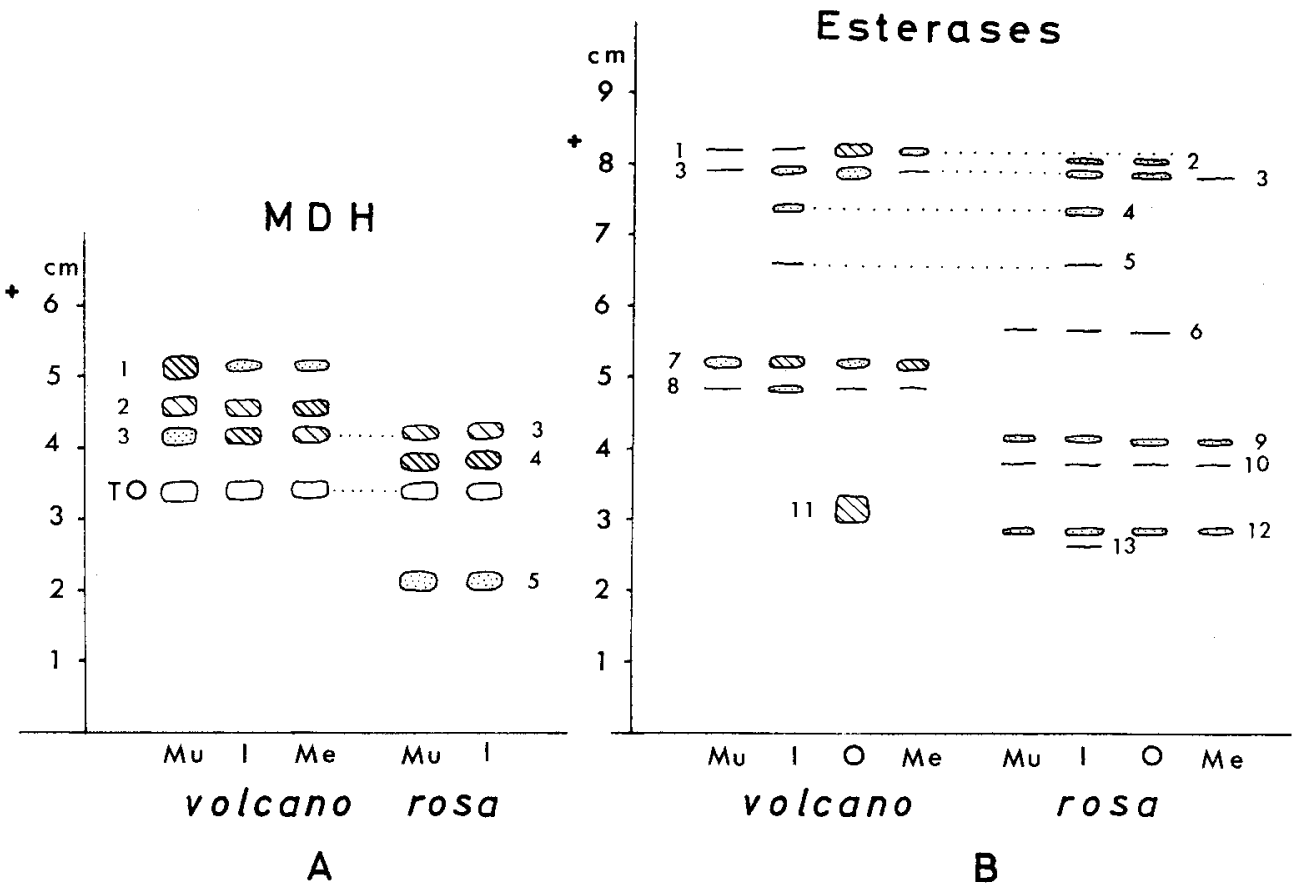

Text-fig. 5. A: Electrophoretic pattern of Malate dehydrogenases of $B .(M$.$) volcano and$ $B$. (M.) rosa. B: Electrophoretic pattern of Esterases of volcano and rosa. Mu: muscle, I: tissues of internal organ, $\mathrm{O}$ : ovary, $\mathrm{Me}$ : opercular membrane. 
together in the following localities: Aburatsubo (Loc. 2), Heta (Loc. 4), Tanabe Bay (Loc. 5), Kôbe Harbor (Kb), Tosa Bay (Loc. 7), Aoshima Is. (Loc. 8), Izumi (Iz), Yaeyama Isls. (Yy), Tomioka (Loc. 11), Sasebo (Ss), Cape Tsuyazaki (Ts), Sakai Harbor (Sk), Wakasa Bay (Wk), Tôjimbô (Tj), and Aikawa (Ak) (Text-fig. 6). Depth

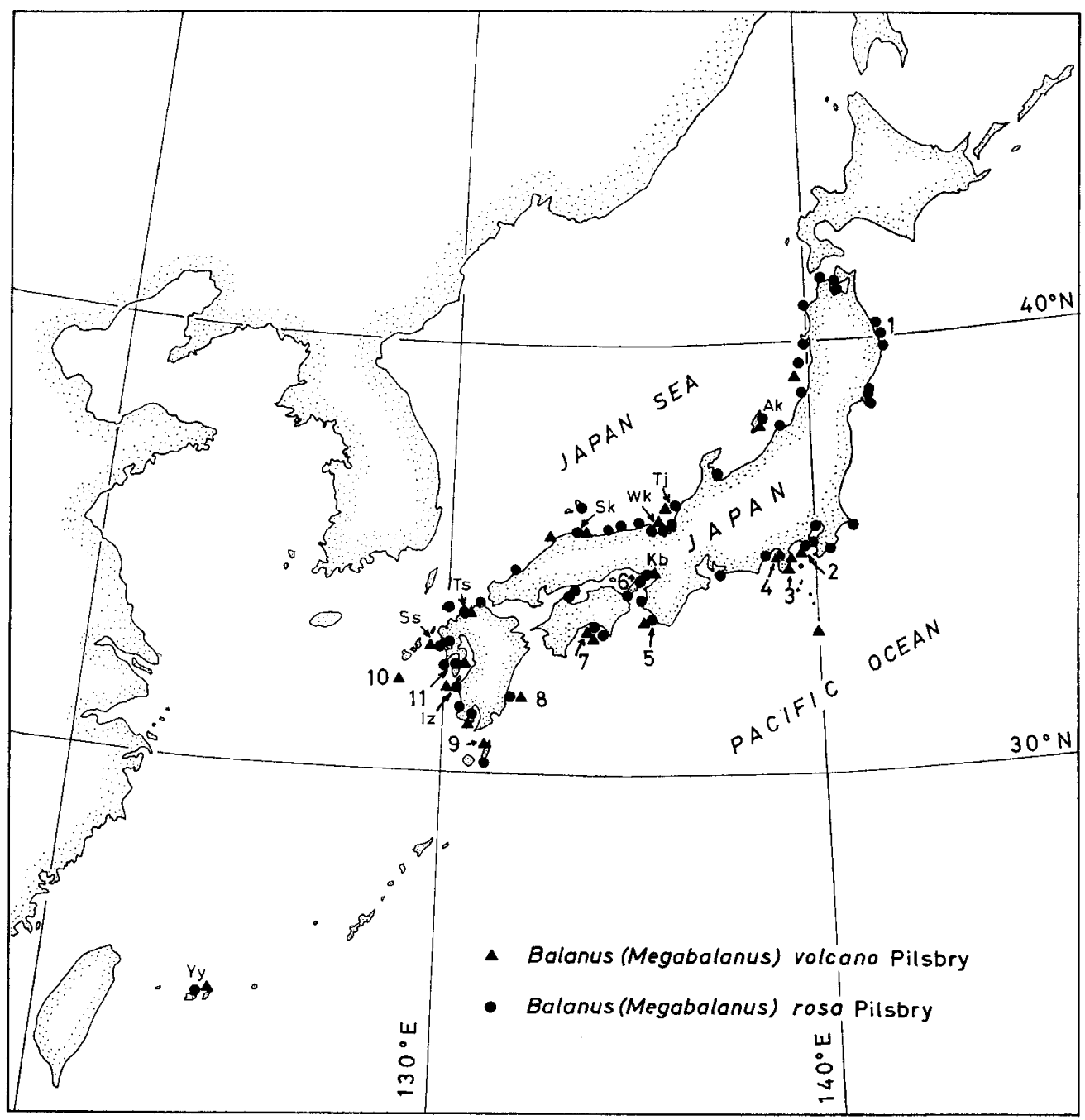

Text-fig. 6. Distribution of $B .(M$.$) volcano and B .(M$.$) rosa in the recent sea. (Compiled from$ Hiro; 1932, 1937 \& 1939b, Nilsson-Cantell; 1927 \& 1932, Pilsbry; 1916, Utinomi; 1949, 1958 \& 1970, Utinomi \& Kikuchi; 1966, Yamaguchi; 1972, MS). Tarasov \& Zevina (1957) reported $B$. (M.) rosa from southern Sakhalin, but they did not show the locality in detail. Ak: Aikawa, Sado Is., Tj: Tôjimbô, Fukui Pref., Wk: Wakasa Bay, Sk: Sakai Harbor, Shimane Pref., Kb: Kôbe Harbor, Hyôgo Pref., Ts: Cape Tsuyazaki, Fukuoka Pref., Ss: Sasebo, Nagasaki Pref., Iz: Izumi, Kagoshima Pref., Yy: Yaeyama Isls., Okinawa Pref. 
distribution, however, seems to be quite different between volcano and rosa. $B .(M$. rosa ranges from 0 to $300 \mathrm{~m}$ in depth, whereas volcano is only found in the lower littoral zone and just below (Hiro, 1937). The sympatric relation in the distribution seems to cast doubt on the subspecific relation these two forms. Thus it becomes important to find out the difference in microenvironment of these two species.

\section{Habitat}

It has been thought that $B .(M$.$) volcano is found attached to rocks below the$ mean tide line, whereas most specimens of $B$. $(M$.) rosa are collected from the submerged surface of buoys and other floating objects. However, the details have remained for further study. In 1971-72 the writer had an opportunity to make detailed observations on the habitat of both these species at Tanabe Bay (Loc. 5). The distribution of both species is shown in text-figure 7 .

In general, volcano lives on rocky shores or on rigid materials below the mean tide line, which is facing the open sea and effected by strong wave action. In Loc. 5, volcano is found attached along rocky shores on the open sea from Locs. $5 \mathrm{~b}$, along the northern rocky shore of headland of Shirahama, $5 \mathrm{~m}, 5 \mathrm{f}, 5 \mathrm{~h}, 5 \mathrm{i}, 5 \mathrm{l}$, to $5 \mathrm{k}$. The number of volcano decreases from the open sea side to the inner bay. In rare cases, this species is also found attached to things floating in the water (e.g., Locs. $5 \mathrm{f}$ and $5 \mathrm{~g}$ ).

In general, rosa is distributed widely throughout the inner bay to the open sea,

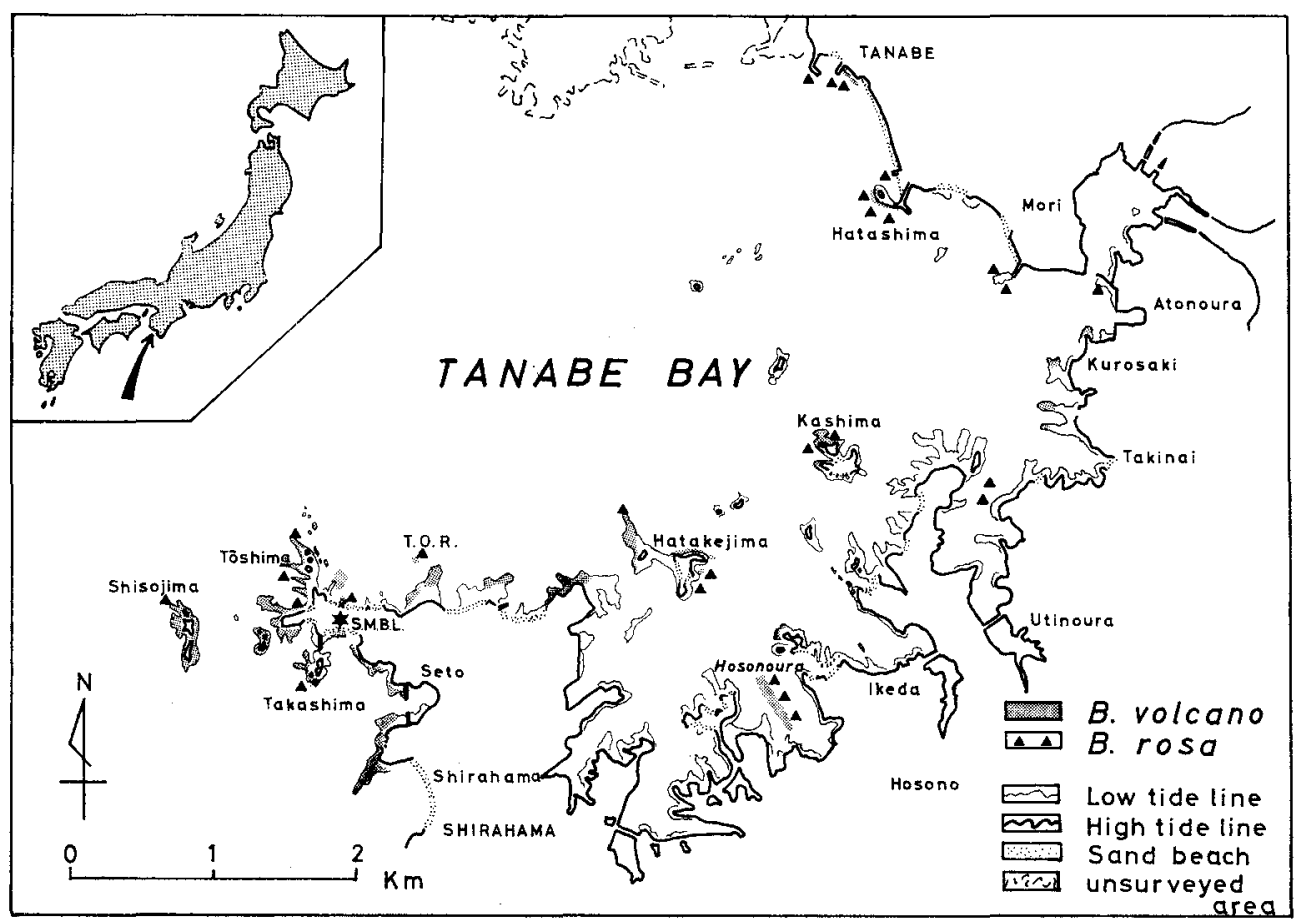

Text-fig. 7. Distribution of $B .(M$.$) volcano and B .(M$.$) rosa in Tanabe Bay (Loc. 5).$ 
living on floating material which is always submerged and protected from strong wave action. This species is rarely found attached to rocky shores or other rigid surfaces. In Tanabe Bay, rosa is generally found on casks and buoys used for culture of pearl and yellowtail.

In many parts of Tanabe Bay volcano and rosa are found side by side. At places which face the open sea (Locs. 5a, 5b, 5c, 5d, 5e, 5f, 5i, and 5l) a few individuals of rosa are associated with many individuals of volcano. In these places rosa is less than $1 \mathrm{~cm}$ in rostro-carinal diameter, which is far smaller than the average diameter of volcano. At the inner part of the Bay, both species are found on casks for pearl culture at Hosonoura, where volcano is mainly attached to the side of casks, while rosa is found attached to the submerged bottom surface (Pl. VIII, fig. 5). In the inner bay rosa is mostly larger than volcano and occurs in greater numbers.

The association of volcano and rosa was also observed at Heta (Loc. 4) and Tosa Bay (Loc. 7). An example of the coexistence of volcano and rosa at Loc. 7 is shown in P1. VIII, fig. 1.

\section{Breeding Season (Mechanism of Reproductive Isolation)}

Breeding season is here defined by the period when mature eggs or nauplius larvae lie in the mantle cavity. Whether or not the eggs attain the mature stage is judged by the dark color of the eggs. During monthly investigations in 1972 in Tanabe Bay (Loc. 5), it was found that the breeding season of $B$. (M.) rosa is March to May (Spring) when the water temperature begins to rise, while that of $B$. (M.) volcano corresponds to the period of maximum water temperature in July to October (Summer to Autum). The period of breeding season seems to be influenced by the temperature

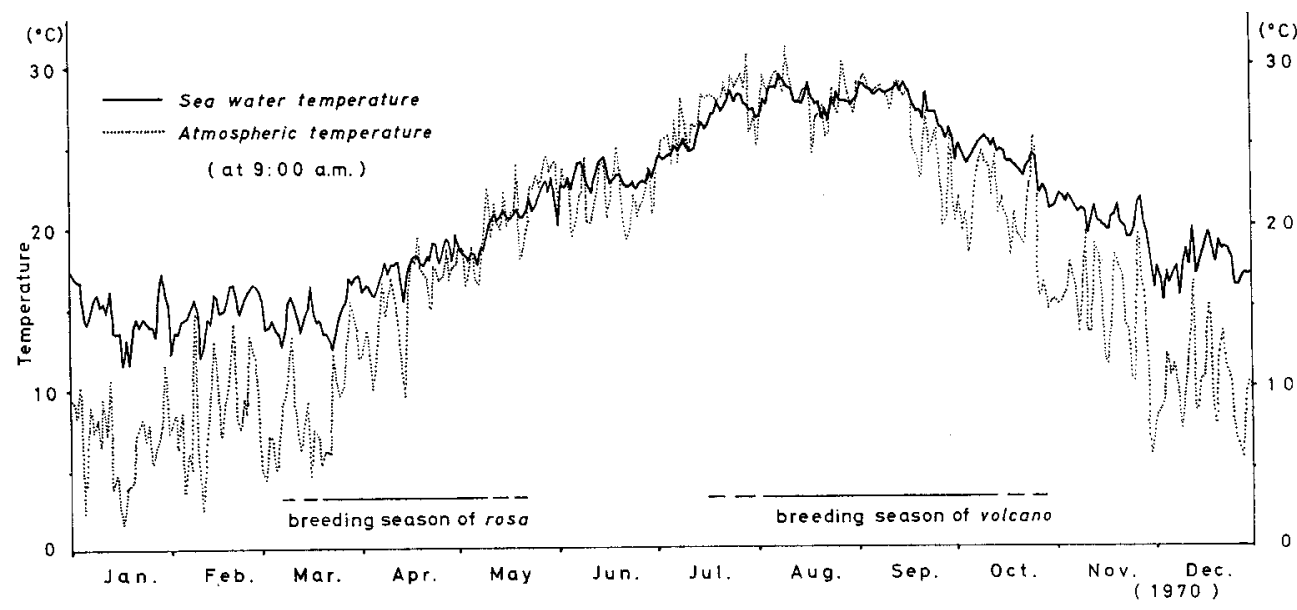

Text-fig. 8. Daily sea water and atmospheric temperatures taken at $9: 00$ a.m. at the southern shore of the Seto Marine Biological Laboratory during 1970 (Based on the Seto Marine Biological Laboratory, 1971). 
of the surface water and hence of the atmospheric temperature (Text-fig. 8). Since the breeding seasons of two forms do not overlap at Tanabe Bay (Loc. 5), these two forms are reproductively isolated.

In Sasebo Bay, Kazihara (1961 and 1964) reported that a test plate submerged in winter was populated by rosa when it was examined in Spring. No previous data are available on the settlement or breeding season of volcano.

\section{Taxonomic Relation between $B$. $(M$ ) volcano and $B$. $(M$.) rosa}

Before entering into discussion of the fossil record, the taxonomic relation between volcano and rosa should be determined, because discussion of the possibility of reproduction between two groups of organisms from different geologic ages is difficult and perhaps meaningless.

Differences in morphology and isozymes exist consistently between volcano and rosa. Examination of distribution, habitat, and breeding season further clarifies the reproductive isolation of the two forms. Therefore by the definition that species are groups of interbreeding natural populations that are reproductively isolated from other such group (Mayr, 1963), it is considered that the taxonomic relation between volcano and rosa is specific rather than subspecific. Hybrids have never been found and thus the speciation seems to be complete.

Darwin, Pilsbry and other authors described many "varieties" and subspecies of $B$. (M.) tintinnabulum before the publication of volcano and rosa by Pilsbry in 1916. The fact that some of them are sympatric [e.g., $B$. (M.) t. tintinnabulum, $B$. (M.) $t$. zebra and $B$. (M.) $t$. occator in the area of Formosa, Philippine and Malay Archipelagos, South China Sea and Indian Ocean (Hiro, 1939a); B. (M.) t. tintinnabulum and $B$. (M.) t. zebra at the mouth of the Bonny River, Nigeria, Africa (Stubbings, 1967); $B$. (M.) t. californicus and $B$. (M.) t. peninsularis in the west coast of the California Peninsula (Pilsbry, 1916) ] raises the suspicion that several synonymous forms may have been described.

\section{Fossil Records}

Neogene and Quaternary fossil barnacles have been investigated to study the change of morphology and ecology. Sampled localities, and names and ages of formations are listed at the end of this section. In spite of the fact that these two species are sympatric, $B .\left(M_{\text {. }}\right)$ volcano has never been found as a fossil, whereas, $B .(M$. rosa has been found abundantly.

Observations were made on the mode of occurrences of fossils to find out morphological and environmental differences between fossil and recens $B$. (M.) rosa. Occurrences of fossil $B$. (M.) rosa can be classified into two types, that is, an autochthonous type, and an allochthonous type. There is no definite boundary between the two types. Autochthonous type is exemplified by $B$. (M.) rosa of the Holocene Ohfuna shell bed (Loc. 25) in which it is found attached to cobbles and in colonies of several 
individuals (Matsushima, personal communication). There are various cases in which the barnacles show evidence of only a little transportation. In the Pleistocene Semata formation (Loc. 19a), B. (M.) rosa is found in association with abundant $B$. rostratus. Both species are found on Chlamys nipponensis. Most of Chlamys occur in living position, as they are found umbo downward. Since $B$. (M.) rosa is found settled on isolated valves of Chlamys, it is interpreted that $B .\left(M_{.}\right)$rosa is transported but the distance of transportation was short. In the Pleistocene Toshima sand (Loc. 28), $B$. (M.) rosa are preserved as complete specimens, some of them even form colonial aggregates (Pl. VIII, fig. 4). In this case, however, all specimens are found separated from the original substrata. It can be concluded that they are transported but not for a long distance.

The allochthonous type is characterized by an abundance of disjointed and fragmental skeletal elements. Most of the occurrences of barnacles are allochthonous (e.g., Pleistocene Miyata formation, Loc. 26, Pl. VIII, fig. 3).

It is possible to infer the habitat of the Pleistocene $B$. (M.) rosa through study of the autochthonous occurrences. The associated molluscs (Loc. 19a: Glycymeris pilsbry, Aequipecten vesiculosus, Chlamys nipponensis, Ancilla hinomotoensis, many other gastropods, etc., Loc. 25: Ostrea belcheri, etc., Loc. 28: Crassostrea gigas, etc.) and the restoration of the Pleistocene paleogeography suggest that $B$. (M.) rosa lived at a considerable range of depth from, at least, just below the lower tide line (Loc. 25 and 28) to $50 \mathrm{~m} \pm$ (Loc. 19a). This figure falls exclusively in the distribution range of living forms and thus no change seems to occur during the Pleistocene on the habitat of $B .(M$.$) rosa. Likewise, there is no difference between the Pleistocene and recent$ $B$. (M.) rosa in outer morphology or in the width of spur of tergum (Text-fig. 1G).

Because of the lack of fossil record for $B$. (M.) volcano, no definite conclusion can be drawn concerning the process of speciation of $B$. (M.) volcano and $B$. (M.) rosa. A possible ancestral form of $B$. $(M$.) rosa can be traced back to the Miocene Takahoko formation (Loc. 16) and the Miocene Misaki formation (Loc. 27), and by the beginning of the Pleistocene $B$. (M.) rosa already occupied an area of distribution similar to the recent.

The absence of $B .(M$.$) volcano in the fossil record may be explained by the rarity$ of shallow water sediments deposited near rocky shores. Further, $B$. (M.) volcano lives in the area of strong wave action where the shell materials are easily destroyed mechanically. Even in the recent sediments it is quite difficult to find fragments of $B$. (M.) volcano.

\section{Fossil Logalities (Text-fig. 9)}

Loc. 12. Kuromatsunai: a cliff $\left(42^{\circ} 41^{\prime 2} 23^{\prime \prime}\right.$ N., $140^{\circ} 18^{\prime} 31^{\prime \prime}$ E.) situated about $2.5 \mathrm{~km}$ north of the Kuromatsunai Station, Kuromatsunai, Suttsu-gun, Hokkaidô. The Pliocene Setana formation (Ikeya, 1971). Barnacles are found in the coarse shell sand ("coquina").

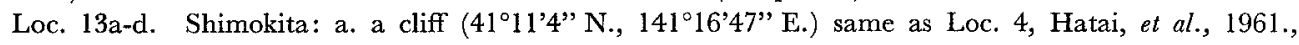
b. a cliff ( $41^{\circ} 11^{\prime} 8^{\prime \prime}$ N., $141^{\circ} 16^{\prime} 56^{\prime \prime}$ E.) of left bank of the Chikagawa River, situated about $150 \mathrm{~m}$ down the river from the bridge of the National Railway., c. a cliff (40 $11^{\prime} 8^{\prime \prime}$ N., $141^{\circ} 16^{\prime} 56^{\prime \prime}$ E.) same as Loc. 
1, Hatai, et al., 1961., d. a cliff (41 $11^{\prime} 17^{\prime}$ N., $141^{\circ} 18^{\prime} 10^{\prime}$ E.) of left bank of the Chikagawa River, situated about $2.4 \mathrm{~km}$ up the stream from the bridge of the Railway, Chikagawa, Mutsu City, Aomori Prefecture. The Pliocene Hamada formation (Yamaguchi, 1970). Cliffs of Locs. 13a-c are composed of pumiceous shell sand ("coquina"). Cliff of Loc. 13d is conglomeratic coarse shell sand.

Loc. 14a, b. Kanita: a, a cliff (41'16'51" N., 140 31'41" E.) situated about $3.5 \mathrm{~km}$ SSE of the Tsugarufutamata Station, b. a cliff (41\%16'51" N., 140 $31^{\circ} 41^{\prime \prime}$ E.) situated about $400 \mathrm{~m}$ SE of the Loc. 14a, Imabetsu, Higashitsugaru-gun, Aomori Prefecture. The Pliocene Kanita formation (Uemura, et al., 1959). Barnacles occur in medium sand containing gravel and shell fragments.

Loc. 15. Daishaka: a cliff $\left(40^{\circ} 46^{\prime} 26^{\prime \prime}\right.$ N., $140^{\circ} 36^{\prime} 52^{\prime \prime}$ E.) same as Loc. D-B-3, Iwai, 1965. The Pliocene Daishaka formation (Iwai, 1965). Barnacles are contained in the tuffaceous sand bearing gravel and abundant shells.

Loc. 16. Obuchi: a road cut (40 58'56" N., $141^{\circ} 21^{\prime} 41^{\prime \prime}$ E.) along the Oippe River, situated about $3 \mathrm{~km}$ NNW of Obuchi, Rokkasho-mura, Kamikita-gun, Aomori Prefecture. The Miocene Takahoko formation (Shibazaki et al., 1958). Barnacles were collected from the poorly sorted and cross-laminated

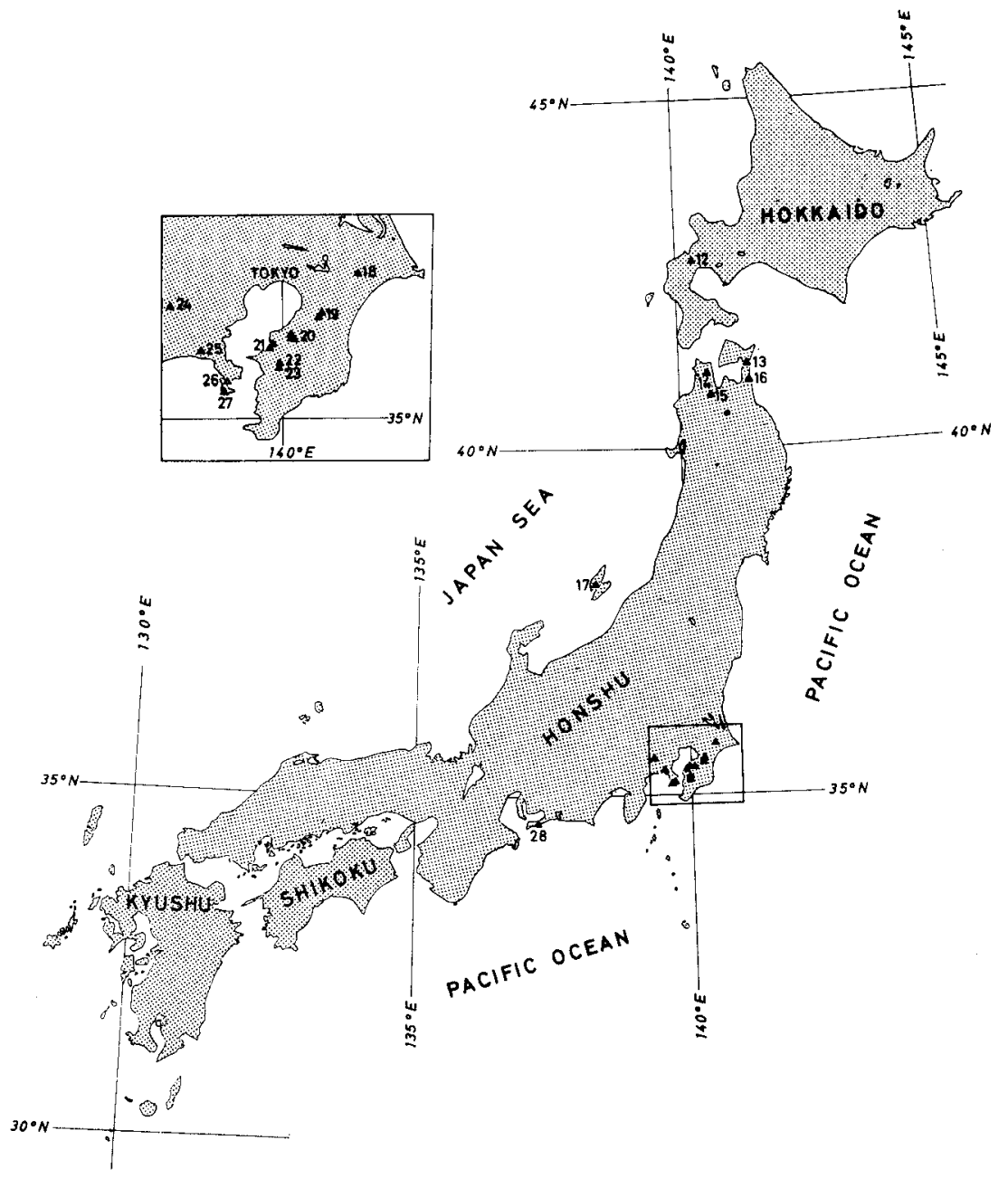

Text-fig. 9. Sampling localities of fossil B. (M.) rosa. 
coarse sand.

Loc. 17. Sado: a cliff ( $35^{\circ} 0^{\prime} 58^{\prime \prime}$ N., $138^{\circ} 16^{\prime} 49^{\prime \prime}$ E.) situated about $1.5 \mathrm{~km}$ NNW of Sawane, Sawada, Sado Island. The Pliocene Sawane formation (Suzuki, $1973 \mathrm{MS}$ ). Barnacles occur in very coarse sand containing much gravel and shells.

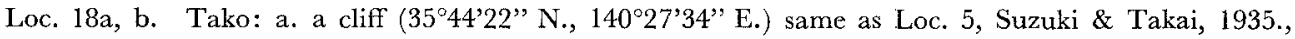

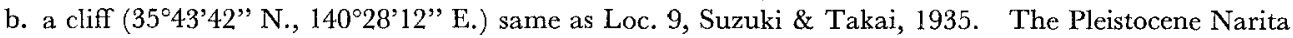
formation (Kikuchi \& Tateno, 1961). Barnacles occur in medium sand at Loc. 18a, and in medium to fine sand at Loc. $18 \mathrm{~b}$.

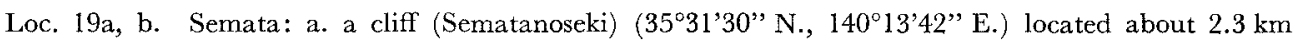
SE of the Honda Station, Takada, Ichihara City. The type-locality of the Pleistocene Semata formation (Ohara, 1968)., b. a cliff (35'29'49" N., 140'11'48' E.) located about $6.7 \mathrm{~km}$ SSW of the Honda Station, Yubukura, Ichihara City, Chiba Prefecture. The Pleistocene Semata formation (Aoki, et al., 1971). Barnacles occur in the coarse shell sand of the Semata shell bed at Loc. 19a, and in the crosslaminated medium sand intercalating fossil bed (Inunari shell bed) at Loc. 19b.

Loc. 20a-c. Kamiizumi: a. cliff ( $35^{\circ} 24^{\prime} 29^{\prime \prime}$ N., 140 $3^{\prime} 6^{\prime \prime}$ E.) located about $3 \mathrm{~km}$ north of the Higashiyokota Station, Kimitsu City, Chiba Prefecture., b. a cliff (35 $24^{\prime} 16^{\prime \prime}$ N., 140 $3^{\prime 2} 26^{\prime \prime}$ E.) situated about $2.8 \mathrm{~km}$ NNE of the Higashiyokota Station., c. a cliff $\left(35^{\circ} 24^{\prime} 39^{\prime \prime}\right.$ N., 140 $3^{\circ} 4^{\prime \prime}$ E.) situated about $3.3 \mathrm{~km}$ north of the Higashiyokota Station. a,b. The Pleistocene Kamiizumi formation (Aoki, et al., 1971). c. The Pleistocene Anegasaki formation (Aoki, et al., 1968). Barnacles were collected from the crosslaminated and well-sorted medium sand at Loc. $20 \mathrm{a}$, from the cross-laminated medium to coarse sand at Loc. $20 \mathrm{~b}$ and from the massive muddy sand correlated to the "Sakurai shell bed" at Loc. 20c.

Loc. $21 \mathrm{a}$, b. Kisarazu: a. a cliff ( $35^{\circ} 22^{\prime} 37^{\prime}$ "N., $139^{\circ} 56^{\prime} 42^{\prime \prime}$ E.) located about $1.5 \mathrm{~km}$ east of the Kisa-

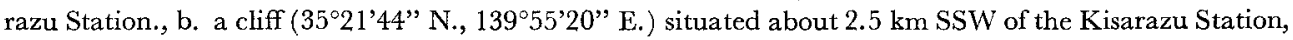
Kisarazu City, Chiba Prefecture. The "Sakurai shell bed" of the Pleistocene Anegasaki formation (Aoki, et al., 1968). Barnacles were collected from the massive muddy sand at Locs. 21a and $21 \mathrm{~b}$.

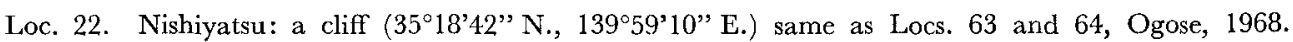
The Pleistocene Nishiyatsu formation (Ogose, 1968). The cliff is composed of cross-laminated medium to coarse sand containing scoria.

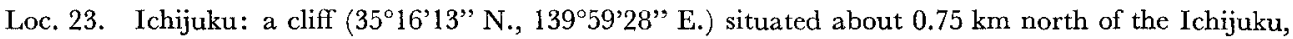
Kimitsu City, Chiba Prefecture. The Pleistocene Ichijuku formation (Sakakura, 1935), Barnacles were obtained from the coarse sand containing scoria and gravel.

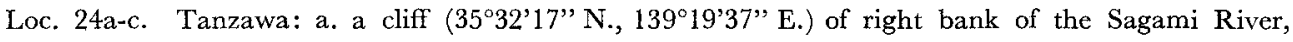
situated about $600 \mathrm{~m} \mathrm{NW}$ of the Takada Bridge which is located about $3.5 \mathrm{~km}$ SW of the Kamimizo Station, Sagamihara City, Kanagawa Prefecture, b. a cliff ( $35^{\circ} 32^{\prime} 4^{\prime \prime}$ N., $139^{\circ} 19^{\prime} 47^{\prime \prime}$ E.) situated about $700 \mathrm{~m} \mathrm{SW}$ of the Takada Bridge., c. a cliff $\left(35^{\circ} 32^{\prime} 0^{\prime \prime}\right.$ N., $139^{\circ} 19^{\prime} 47^{\prime \prime}$ E.) situated about $700 \mathrm{~m} \mathrm{SW}$ of the Takada Bridge. The Pliocene Kosawa sandstone and conglomerate member (Kozima, 1955) of the Nakatsu formation. Barnacles were collected from the conglomeratic medium sand.

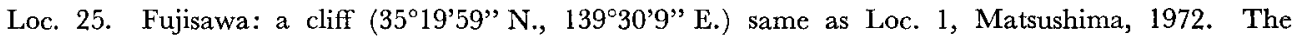
Holocene Ohfuna shell bed (Matsushima, 1972). Barnacles are attached to the gravel forming colonies.

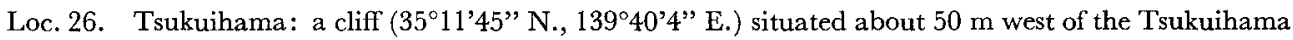
Station, Miura City, Kanagawa Prefecture. The Pleistocene Miyata formation (Yamaguchi, 1971). Barnacles are contained in the cross-laminated medium to coarse sand including pumice, scoria and gravel.

Loc. 27. Misaki: a cliff (35'8'8' N., $139^{\circ} 37^{\prime} 42^{\prime \prime}$ E.) situated about $100 \mathrm{~m}$ east of the Jôgashima-Ohashi Bridge, Miura City, Kanagawa Prefecture. The Miocene Misaki formation (Koike \& Murai, 1950). Barnacles are collected from the coarse sand which contains scoria and gravel.

Loc. 28. Atsumi: a cliff $\left(34^{\circ} 37^{\prime} 7^{\prime \prime}\right.$ N., 137 $14^{\prime} 49^{\prime \prime}$ E.) same as Loc. 135, Hayasaka, 1961. The Pleistocene Toshima sand (Hayasaka, 1961). Barnacles are contained in fossiliferous massive medium sand. 


\section{Conclusion}

Two subspecies of Balanus, Balanus (Megabalanus) tintinnabulum volcano Pilsbry, and $B .(M$.$) tintinnabulum rosa Pilsbry, are morphologically and biochemically distinct$ with largely overlapping geographic ranges. Where the ranges overlap, they occupy similar but in detail different habitats; $B$. $(M$.) volcano lives on rigid rocky shores, while $B$. (M.) rosa attaches to floating objects. The difference in the breeding season seems to be effective for reproductive isolation of the two groups. Therefore, the relation between the two groups should be considered specific rather than subspecific.

The fossil record of $B$. (M.) rosa goes back to the Miocene, while $B$. (M.) volcano is only in the recent. This may be not because $B$. (M.) volcano is a relative new comer to the Japanese coast, but because $B$. (M.) volcano lives in an environment where the shell is easily destroyed by wave action, and further, because it is very rare to find sediments deposited in this environment in the geological past.

\section{Systematic Descriptions}

Family Balanidae Leach, 1817

Subfamily Balaninae Leach, 1817

Genus Balanus Da Costa, 1778

Subgenus Megabalanus Hoek, 1913

\section{Balanus (Megabalanus) rosa Pilsbry}

(Pl. VI, figs. la-j, 3, 6, 7, Pl. VII, figs. 3a-4b, Pl. VIII, figs. 1-2b, Text-fig. 10)

Balanus (Megabalanus) tintinnabulum rosa Pilsbry, 1916, p. 61; Tarasov \& Zevina, 1957, p. 164, figs. 54-55;

Yamaguchi, 1971, p. 124, pl. 5, figs. 1-7.

Balanus tintinnabulum rosa Pilsbry, Nilsson-Cantell, 1932, p. 16, text-fig. 6, pl. 1, fig. 3; Hiro, 1932, p.

549, text-fig. 3; Hiro, 1937, p. 431, text-fig. 19B; Yabe \& Hatai, 1941, p. 78.

Diagnosis. Parietes yellowish red to reddish purple, radii rather dark in color. Surface of parietes smooth. Scutum flat with prominent growth ridges. Tergum with rather wide spur. Width of spur nearly equal to the distance between anterior side of spur and basiscutal angle. Basal margin of tergum usually straight. Mandible with four large teeth, and with minute and bluntly rounded fifth and sixth teeth.

Description. General appearances: Shell conical, smooth and thick, yellowish red to reddish purple, in some cases white, with faint longitudinal stripes of shades of color. Radii and area near orifice darker than the other part of parietes.

Compartments: Parietes conical and smooth. Longitudinal tubes with transverse septa in upper most portion. Surface of inner lamina slightly ribbed or smooth. Radii rather wide and porous, with septa, denticulate along the edges of the compartment. The summits of radii nearly parallel to the base. External surface of radii smooth, often with many slight horizontal stripes reflecting existence of septa. Alae 
narrow, and their summits oblique to the base. Sheath smooth, reddish purple to light purple or white in color. Orifice large and pentagonal to rhomboidal.

Bases: Calcareous, thick and porous. Form varies according to shape of external obstacles.

Opercular valves: Scutum broad and triangular, with prominent growth ridges imbricated downward, and slight longitudinal depression. Color of scutum reddish purple on external and reddish purple to light purple on internal surface. External surface of scutum flat or warped outerward at apex. Articular ridge prominent and reflexed, with longitudinal striations of callus-like faint projections in large specimens. Articular furrow narrow and shallow. Adductor ridge blunt and prominent, and confluent with articular ridge, and running straight down the scutum bounding the edge of pit for lateral depressor muscle. Pit for adductor muscle and for lateral depressor muscle wide and deep. In very rare cases, basal margin of the scutum and pit for lateral depressor muscle with faint longitudinal striations. Basal margin of scutum generally indistinctly concave near occludental side and slightly convex near tergal side. Tergum broad with weak growth ridges. Color of tergum white with purple pink along the scutal margin and along the longitudinal area between carinal margin and spur furrow. Spur furrow deep and barely open. Spur long with width nearly equal to the distance between anterior side of spur and basiscutal angle. Spur obliquely truncated at end. Articular ridge long, acute, and prominent, running from apex toward basiscutal angle. Longitudinal ridges at carinal side of articular ridge very weak but numerous and parallel to articular ridge. Scutal edge high and acute. Crests for depressor muscle very weak. Basal margin of tergum nearly straight.

Opercular membrane: Opercular membrane of aperture contains some dark green pigment.

Mouth parts (Text-fig. 10): Labrum with two or three teeth on both sides of labrum notch and with numerous very fine setules aligned in several lines on the edge. Mandible with four large teeth and minute but bluntly rounded fifth and sixth teeth, and with closely set setae covering the narrow stripe between the main part of mandible and tooth edge. Mandibular palp oval with closely set setae. Maxilla I with two large spines at distal angle; another two large spines near lower distal angle; six to eleven medium sized spines between upper and lower large spines; several small spines and spinules at lower distal angle; small, narrow and deeply concave notch just below two upper large spines; and with closely set setae between upper and lower edges. Maxilla II oval with closely set setae.

Cirri (Text-fig. 10): Number of segments in each cirrus is shown in text-figures 2 and 3. Exopodite of cirrus I approximately twice as long as endopodite. Anterior face of each segment in endopodite of cirrus I and both rami of cirrus II remarkably protuberant. Exopodite of cirri II and III nearly equal to its endopodite in length, but exopodite having more segments than endopodite. Cirrus III with many spinules in a row along distal border of each segment. In cirri IV to VI, exopodite nearly equal to endopodite in length and number of segments, with many spinules in a row 
T. YamaguahI
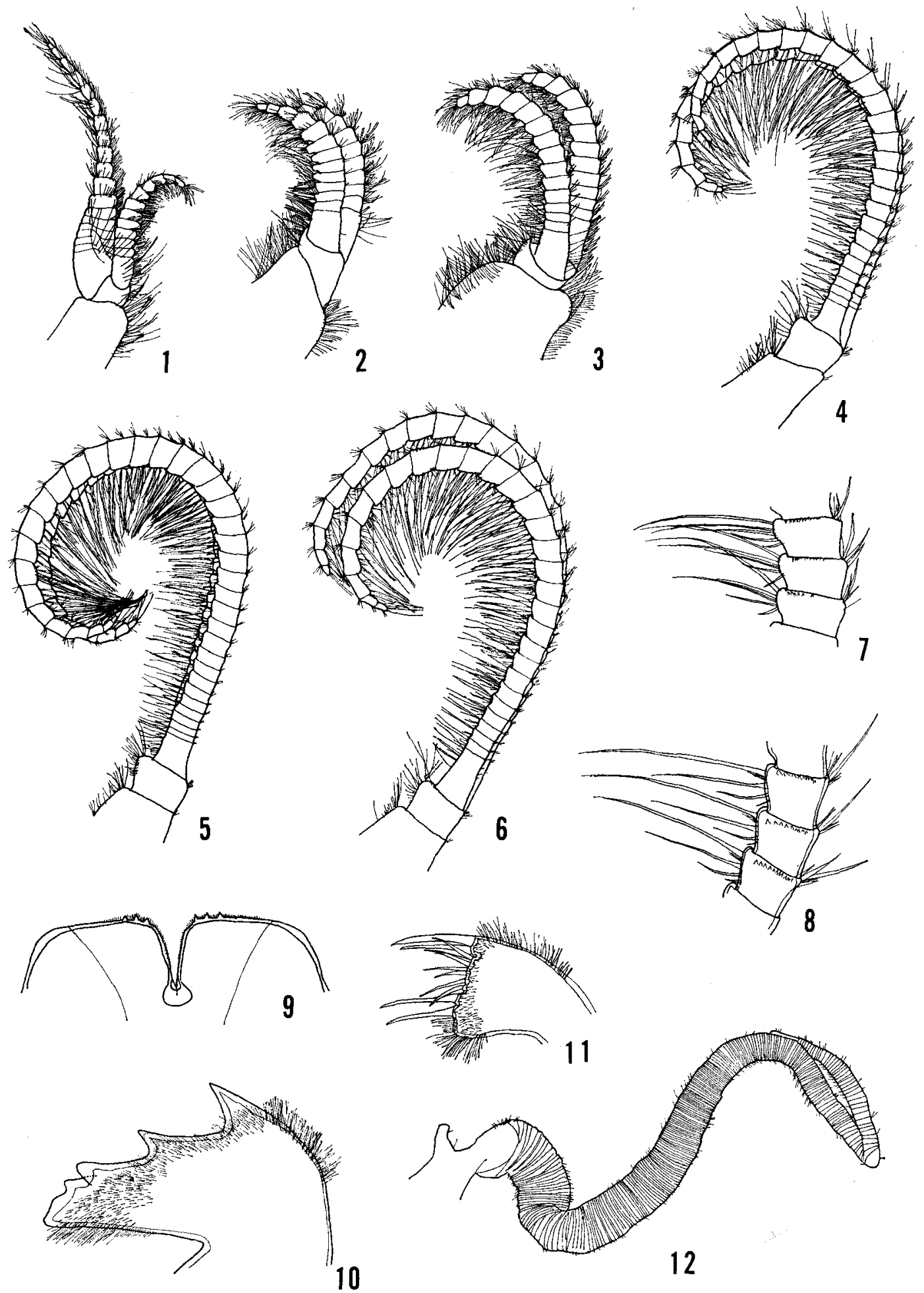

12 
at distal border of each segment. Median segments of cirri IV to VI with four or three paired spines which gradually shorten from distal to proximal side, and with spinules on anterior face between distal two paired large spines.

Penis (Text-fig. 10): Longer than cirri with short and blunt dorsal point and with very fine setae.

REMARKs. 29 specimens were obtained for dissection on April 13, 1971, and on August 11, 1972, from Tanabe (Loc. 5m), where the species are found attached to rocks, frequently embedded in sponges or coverved with bryozoans, and associated with Chthamalus challengeri Hoek, Tetraclita squamosa japonica Pilsbry, and Balanus trigonus Darwin in a zone a little above the mean tide line.

\section{Balanus (Megabalanus) volcano Pilsbry}

(Pl. VI, figs. 2a-j, 4, 5, Pl. VII, figs. 1a-2b, Pl. VIII, figs. 1-2b, Text-fig. 11)

Balanus (Megabalanus) tintinnabulum volcano Pilsbry, 1916, p. 60; Hiro, 1937, p. 430, text-fig. 19A; Tarasov \& Zevina, 1957, p. 165.

Balanus tintinnabulum volcano Pilsbry, Nilsson-Cantell, 1932, p. 19, text-fig. 7.

Balanus (Megabalanus) tintinnabulum peninsularis Pilsbry, Nilsson-Cantell, 1927, p. 783, text-fig. 18.

Diagnosis. Parietes reddish purple to faint purple, radii faint in color. Surface of parietes rough and often with many spines. Scutum flat with weak growth ridges. Tergum with narrow and long spur. Width of spur nearly equal to the half to onethird of distance between anterior side of spur and basiscutal angle. Basal margin of tergum comes near to the tip of the spur on scutal side and runs away from the tip of the spur on the carinal side. Mandible with four large teeth and minute and sharply pointed fifth and sixth teeth.

Description. General appearances: Shell conical, rather thick and strong, reddish purple to light purple with longitudinal stripes of shades of color, and with rough surface or with minute and downwardly projecting spines. Color of radii more faint than that of parietes.

Compartments: Parietes conical and in general rough, or with minute spines projecting obliquely downward. In large specimens surface become smooth by erosion. The distribution of transverse septa of longitudinal tubes, nature of surface of inner lamina, shape and structure of radii and alae, and size and shape of orifice are all essentially the same as those found in $B .(M$.) rosa.

Bases: Calcareous, thick and porous, but not so elongate as in $B .(M$.$) rosa.$

Opercular valves: Scutum broad and triangular, surface rather smooth with faint growth ridges, very weak longitudinal striations and slight longitudinal depression.

Text-fig. 10. Balanus (Megabalanus) rosa Pilsbry (UMUT-RA8197) 1-6. right cirri I to VI, lv., $\times 14,1$ : cirrus $I, 2$ : cirrus II, 3 : cirrus III, 4 : cirrus IV, 5 : cirrus $V, 6$ : cirrus VI., 7. 7th to 9 th segments of exopodite of right cirrus III, 1v., $\times 33 ., 8.14$ th to 16 th segments of right cirrus $I V, 1 \mathrm{v}$, $\times 33$., 9. labrum, av., $\times 33 ., 10$. right mandible, 1v., $\times 33 ., 11$. right maxilla I, 1v., $\times 33 ., 12$. penis, $1 \mathrm{v} ., \times 14$. 
T. YAMAGUCHI
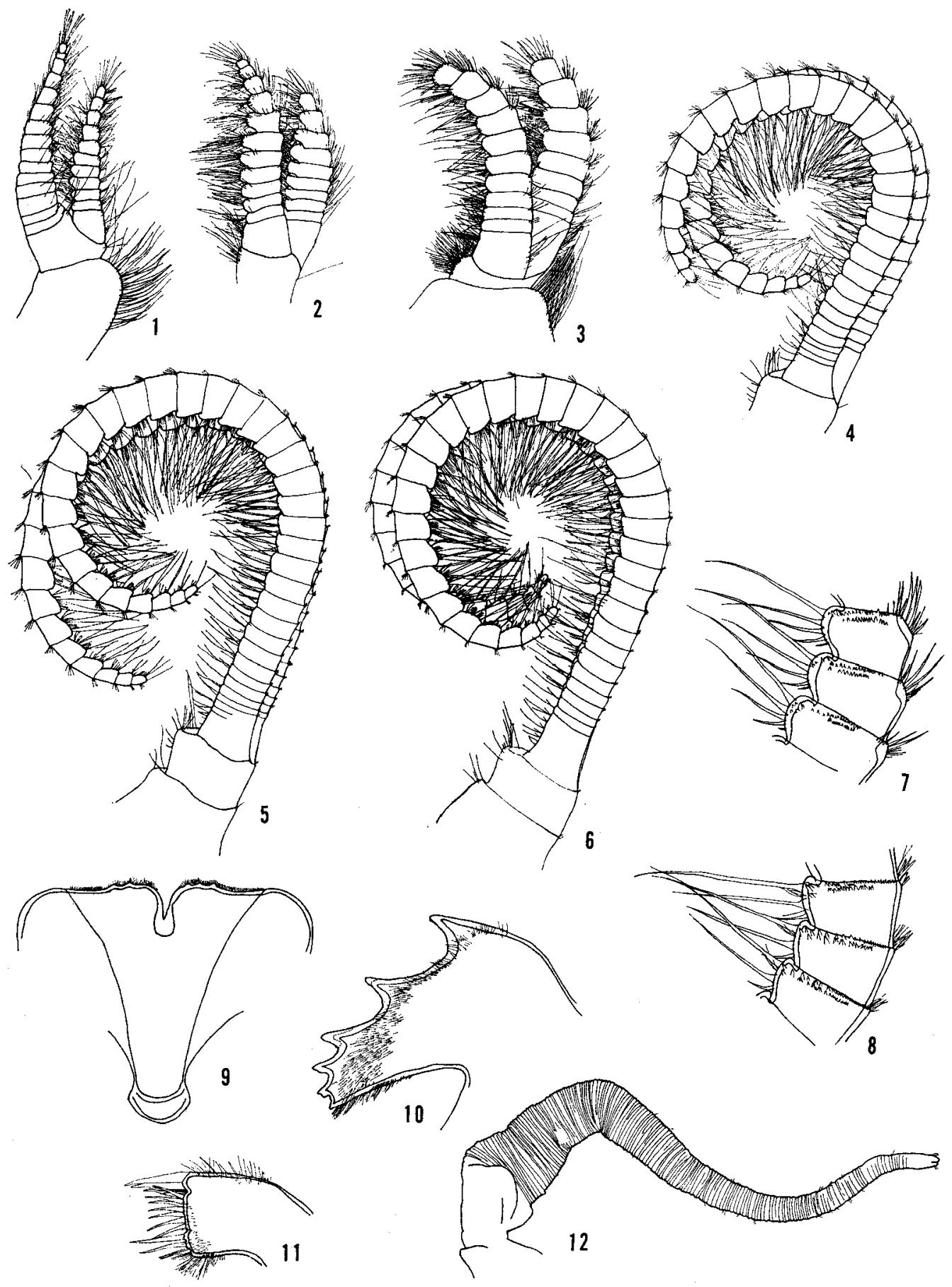
Folding of the projecting portion of ridges develops at each intersection between faint growth ridges and longitudinal striations. Folding especially prominent in large specimens. Color of scutum reddish purple to pale purple on external and dark purple on internal surface. External surface of scutum flat. Basal margin of scutum nearly straight, or indistinctly concave at the center of basal margin. Tergum broad and rather smooth with weak growth ridges and very weak longitudinal striations. Spur furrow closed and deep in general. Spur long with nearly equal to half to one-third of distance between anterior side of spur and basiscutal angle, and obliquely truncated at end. Basal margin of tergum comes near to the tip of the spur on scutal side and runs away from the tip of the spur on the carinal side. Shape of articular furrow, articular ridge, adductor ridge, pit for adductor muscle, pit for lateral depressor muscle, scutal edge, crests for depressor muscle, and color of tergum are all nearly identical to those of $B$. (M.) rosa.

Opercular membrane: Epidermis of aperture has dark green pigment.

Mouth parts (Text-fig. 11): Arrangement pattern of teeth and setules on labrum are same as those of $B$. (M.) rosa. Mandible with large first to fouth teeth, minute and sharply pointed fifth and sixth teeth. Distribution pattern of setae on mandible and mandibular palp, and distribution and number of main spines on maxilla I are same as those of found in $B$. (M.) rosa. Shape and distribution of setae on maxilla II are again same as those of $B .(M$.) rosa.

Cirri (Text-fig. 11): Number of segments in each cirrus is shown in text-figures 2 and 3. Exopodite of cirri I and II larger than endopodite in length and number of segments. Anterior face of each segment in endopodite of cirrus I and both rami of cirrus II are as remarkably protuberant as those in $B$. (M.) rosa. Relative length and relative number of segments between exopodite and endopodite of cirri II and III are same as in $B .(M$.) rosa. In cirri III to VI, one or two rows of many fine spinules at distal border of each segment. Number of segments, relative length between exopodite and endopodite and arrangement of spinules in cirri IV to VI are same as those of $B$. (M.) rosa.

Penis (Text-fig. 11): No difference can be detected in the morphology of penis between $B .(M$.$) volcano and B .(M$.$) rosa.$

Remarks. A total of 27 specimens collected from Tôshima Is. (Loc. 5c) on March 27, 1971, and on August 26, 1972, were dissected. This species lives on a rocky substratum, frequently embedded in sponges, attached to sessile or slowly moving molluscan shells, and associated with Tetraclita squamosa japonica Pilsbry and Pollicipes mitella (Linné). Common in the zone between mean tide and lower tide line.

Text-fig. 11. Balanus (Megabalanus) volcano Pilsbry (UMUT-RA8202) 1-6. right cirri I to VI, 1v., $\times 10$, 1: cirrus I, 2: cirrus II, 3 : cirrus III, 4 : cirrus IV, 5 : cirrus V, 6 : cirrus VI., 7. 7th to 9 th segments of exopodite of right cirrus III, $1 \mathrm{v} ., \times 23.7 ., 8$. 14 th to 16 th segments of exopodite of right cirrus IV, 1v., $\times 23.7 ., 9$. labrum, av., $\times 23.7 ., 10$. right mandible, 1v., $\times 23.7 ., 11$. right maxilla $I, 1 v ., \times 23.7 ., 12$. penis, $1 \mathrm{v}$., $\times 10$. 


\section{Acknowledgements}

First of all, this article is respectfully dedicated to Professor Huzio Utinomi, pioneer of the study of Japanese Cirripedia, on the occasion of his retirement from the Seto Marine Biological Laboratory of Kyoto University.

Professor Tetsuro Hanai of the University of Tokyo read the manuscript and gave the writer invaluable advice. Dr. Ken-ichi Numachi and Miss Machiko Oya of the Ocean Research Institute of the University of Tokyo gave the writer helpful advice on gel electrophoresis of isozymes. Dr. Masuoki Horikoshi of the Ocean Research Institute of the University of Tokyo, Dr. Sakae Ohara of Chiba University, Dr. Yukito Enomoto of Kobe University, Mr. Yoshiaki Matsushima of the Kanagawa Prefectural Museum and Mr. Yasumitsu Kanie of the Yokosuka City Museum provided samples for comparative study. Drs. Takasi Tokioka, Shin-ichiro Fuse, Saburo Nishimura and other scientists of the Seto Marine Biological Laboratory of Kyoto University, and Drs. Kiyotaka Chinzei and Yasuhide Iwasaki of the University of Tokyo provided useful discussion. Mr. John Grimmer of the University of California, Los Angeles, read the manuscript. To all these people the writer express his sincere appreciation.

\section{REFERENCES}

Aoki, N. and Baba, K. 1971. Molluscan fossil assemblages and their stratigraphic positions in the Semata, Kamiizumi and Narita formations of the Kisarazu-Ichihara area, Boso Peninsula. Jour. Geol. Soc. Japan, v. 77, p. 137-151.

- 1972. Pleistocene stratigraphy of the northeastern part of Chiba Prefecture. Jour. Geol. Soc. Japan, v. 78, p. 65-73.

, Horiguchi, O. and Baba, K. 1970. Pleistocene deposits in the environs of Anegasaki-Chiba City, Boso Peninsula. Jour. Geol. Soc. Japan, v. 76, p. 303-308.

- _- _ - Yamashita, F. and Kamijo, H. 1968. Pleistocene deposits in the environs of Kisarazu and Anegasaki, Boso Peninsula. Jour. Geol. Soc. Japan, v. 74, p. 319-325.

Darwin, C. R. 1854. A monograph on the sub-class Cirripedia, with figures of all the species. Ray Soc. Publ., London, p. 1-684.

Hatai, K., Masuda, K. and Suzuki, K. 1961. A note on the Pliocene megafossil fauna from the Shimokita Peninsula, Aomori Prefecture, northeast Honshu, Japan. Saito Ho-on Kai Mus., Res., Bull., no. 30 , p. 18-38.

Hayasaka, S. 1961. The geology and paleontology of the Atsumi Peninsula, Aichi Prefecture, Japan. Sci. Rept. Tohoku Univ., 2nd. ser. (Geol.), v. 33, p. 1-103.

Hiro, F. 1932. Report of the biological survey of Mutsu Bay. 25. Cirripedia. Sci. Rept., Tohoku Imp. Univ., 4th ser. (Biol.), v. 7, p. 545-552.

1933. Report on the Cirripedia collected by the survering ships of the Imperial Fisheries Experimental Station on the continental shelf bordering Japan. Rec. Oceanogr. Works Japan, v. 5 , p. $11-84$.

1935. The fauna of Akkeshi Bay. II. Cirripedia (Studies on the Cirripedian fauna of Japan.

I.). Jour. Fac. Sci., Hokkaido Imp. Univ., ser. VI, v. 4, p. 213-229.

1937. Studies on Cirripedian fauna of Japan. II. Cirripeds found in the vicinity of the Seto Marine Biological Laboratory. Mem. Coll. Sci., Kyoto Imp. Univ., ser. B, v. 12, p. 385-478.

1938. On the Japanese forms of Balanus amphitrite Darwin. Zool. Mag. Japan, v. 50, p. 299-313. 
1939a. Studies on Cirripedian fauna of Japan. IV. Cirripeds of Formosa (Taiwan), with some geographical and ecological remarks on the littoral forms. Mem. Coll. Sci., Kyoto Imp. Univ., ser. B, v. 15, p. 245-284.

1939b. Studies on the Cirripedian fauna of Japan. V. Cirripeds of the northern part of Honshu. Sci. Rept. Tohoku Imp. Univ., Biol., v. 14, p. 201-218.

Ikeya, N. 1968. Structure and succession of foraminiferal populations. Dissertation Thesis, Geol. Inst., Univ. Tokyo (MS).

Ito, T. 1959. Marine sedentary communities with special reference to the succession in the Inland Sea of Japan. Bull. Mar. Biol. Stat. Asamushi, v. 9, p. 161-165.

Iwai, T. 1965. The geological and paleontological studies in the marginal area of the Tsugaru Basin, Aomori Prefecture, Japan. Bull. Educ. Fac. Hirosaki Univ., no. 15, p. 1-68.

Kazihara, T. 1961. Studies on the attaching materials on the nets. -III. Seasonal settlements of animal fouling organisms. Bull. Fac. Fish. Nagasaki Univ., no. 11, p. 49-64.

1964. Ecological studies on marine fouling animals. Bull. Fac. Fish. Nagasaki Univ., no. 16, p. $1-138$.

Kikuchi, T. and Tateno, T. 1962. Pleistocene deposits of the environs of Edosaki-machi, Ibaragi Prefecture and Tako-machi, Chiba Prefecture. Jour. Geol. Soc. Japan, v. 68, p. 17-28.

Koike, K. and Murai, I. 1950. Fundamental study of tuffs in southern Kantô (part 1). Bull. Physiogr. Sci., Res. Inst. Tokyo Univ., no. 5, p. 22-26.

Kozima, N. 1955. On the fossil shells in the Nakatu Superformation, developed in the Nakatu District, Kanagawa Prefecture, south Kantô, Japan. Jour. Geol. Soc. Japan, v. 61, p. 449-456.

Kraus, A. P. and Keely, C. L. 1964. Human Erthrocyte Lactate dehydrogenases: Four genetically determined variants. Sci., v. 145, p. 595-597.

Matsushima, Y. 1972. Molluscan assemblages of the Inner part of Paleo-Ofuna Bay, central Kanagawa Prefecture. Bull. Kanagawa Pref. Mus., v. 1, p. 31-43.

Mayr, E. 1963. Animal species and evolution. Belknap Press, Harvard Univ. Press, Cambridge, Mass.

Newman, W. A., Zullo, V. A. and Withers, T. H. 1969. Cirripedia, p. 206-295, in Moore (ed.) Treatise on Invertebrate Paleontology (R) Arthropoda 4 (1), Geol. Amer., Inc. \& Univ. Kansas.

Nilsson-Cantell, C. A. (1927) Some barnacles in the British Museum (Nat. Hist.). Proc. Zool. Soc., pt. 2, p. 743-790.

1932. Cirripedien aus Japan. Ark. Zool., bd. 24 A, p. 1-30.

Ogose, S. 1968. Molluscan fossils from the Nishiyatsu sand, Tiba Prefecture, south Kantô, Japan. Jour. Geol. Soc. Japan, v. 74, p. 203-216.

Ohara, S. 1968. The type Semata formation. Jour. Coll. Art. \& Sci., Cihiba Univ., v. 5, p. $303-318$.

Pilsbry, H. A. 1916. The sessile barnacles (Cirripedia) contained in the collections of the U.S. National Museum; including a monograph of the American species. Bull. U.S. Natl. Mus., no. 93, p. 1366.

Sakakura, K. 1935. The stratigraphy of the Obitugawa Basin, Tiba Prefecture (part 1). Jour. Geol. Soc. Japan, v. 42, p. 685-712.

Seto Marine Biological Laboratory 1971. Oceanographic data at the S. M. B. L., 1970. Publ. Seto Mar. Biol. Lab., v. 18, p. 413-419.

Shibazaki, T., Aoki, S., Komatsu, N., Omori, R. and Fujita, Y. 1958. On the geology and the groundwater in the southern part of the Shimokita Peninsula, Aomori Prefecture, Japan. Jubilee Publ., Prof. H. Fujimoto Sixtieth Birthday, p. 154-160.

Stubbings, H. G. 1967. The cirriped fauna of tropical west Africa. Bull. Br. Mus. nat. Hist. (Zool.), v. 15 , p. $227-319$.

Suzuki, K. and Takai, H. 1935. Fossiliferous beds in the vicinity of 'Tako-mati, Tiba Prefecture. Jour. Geol. Soc. Japan, v. 42, p. 1-35.

Suzuki, N. 1973. Geology and foraminiferal fossil assemblages of the Sawane district, Sado-gun, Niigata Prefecture. Bachelor Thesis, Univ. Tokyo (MS).

Uemura, F., Tsushima, K. and Sitô, M. 1959. Geological map, Kanita (scale $1: 50,000$ ). Geol. Surv. Japan, p. 1-30. 
Utinomi, H. 1949. Studies on the Cirripedian fauna of Japan. VI. Cirripeds from Kyusyu and Ryukyu. Publ. Seto Mar. Biol. Lab., v. 1, p. 19-37. 1955. Studies on the Cirripedia of Japan. II. Geographical distribution. Biogeogr. Soc. Japan, Bull., v. 16-19, p. 113-123.

1958. Studies on the Cirripedian fauna of Japan. VII. Cirripeds from Sagami Bay. Publ. Seto Mar. Biol. Lab., v. 6, p. 281-311.

1962. Studies on the Cirripedian fauna of Japan. VIII. Thoracic cirripeds from western Kyushu. Publ. Seto Mar. Biol. Lab., v. 10, p. 211-239.

1967. Comments on some new and already known cirripeds with emended Taxa, with special reference to the parietal structure. Publ. Seto Mar. Biol. Lab., v. 15, p. 199-237.

1970. Studies on the Cirripedian fauna of Japan. IX. Distributional survey of Thoracic cirripeds in the southeastern part of the Japan Sea. Publ. Seto Mar. Biol. Lab., v. 17, p. 339-372.

- and Kikuchi, T. 1966. Fauna and flora of the sea around the Amakusa Marine Biological

Laboratory. Part VI. Cirriped Crustacea. Amakusa Mar. Biol. Lab., Kyushu Univ., p. 1-11. Yabe, H. and Hatai, K. M. 1941. Additional fossils from the Shimaziri beds of Okinawa-zima, Ryukyu Islands, Japan. Jap. Jour. Geol. Geogr., Trans., v. 18, p. 71-78.

Yamaguchi, T. 1970. The Neogene of the northeastern part of the Shimokita Peninsula, Northeast Honshu, Japan. - On the stratigraphic relation of the Tomari, the Gamanosawa and the "Sunagomata" formations-. Jour. Geol. Soc. Japan, v. 76, p. 185-197.

1971. Fossil barnacles from the Pleistocene Miyata formation. Sci. Rept., Yokosuka City Mus., no. 18, p. 122-129.

1972. Fossil barnacles in Japan. MSc. Thesis, Univ. Tokyo (MS). 


\section{EXPLANATION OF PLATES VI-VIII}

\section{PLATE VI}

Fig. 1. Balanus (Megabalanus) rosa Pilsbry (UMUT-RA8198) from Tanabe (Loc. 5c). Associated with Chthamalus challengeri Hoek. la-b.. whole wall, $\times 1.7$, Ic-d, exterior and interior views of right tergum, $\times 4.4$., le-f, exterior and interior views of left tergum, $\times 4.4 ., 1 \mathrm{~g}-\mathrm{h}$, exterior and interior views of right scutum, $\times 4.4 ., 1 \mathrm{i}-\mathrm{j}$, exterior and interior views of left scutum, $\times 4.4$.

Fig. 2. Balanus (Megabalanus) volcano Pilsbry (UMUT-RA8202) from Tôshima Is. (Loc. 5c). $2 a-b$, whole wall, $\times 1.7 ., 2 c-d$, exterior and interior views of right tergum, $\times 3.5$., $2 \mathrm{e}-\mathrm{f}$, exterior and interior views of left tergum, $\times 3.5 ., 2 \mathrm{~g}-\mathrm{h}$, exterior and interior views of right scutum, $\times 3.5,2 \mathrm{i}-\mathrm{j}$, exterior and interior views of left scutum, $\times 3.5$.

Fig. 3. $B$. (M.) rosa Pilsbry (UMUT-RA8199) from Tanabe (Loc. $5 \mathrm{~m}$ ). $\times 1.7$. (white form).

Fig. 4. B. (M.) volcano Pilsbry (UMUT-RA8201) from Tôshima Is. (Loc. 5c). $\times 1.7$. (with spines).

Fig. 5. B. (M.) volcano Pilsbry (UMUT-RA8200) from Tôshima Is. (Loc. 5c). ×1.7. (coarse surface).

Fig. 6. Fossil B. (M.) rosa Pilsbry (UMUT-GA8205) from the Holocene Ohfuna shell bed (Loc. 25). $\times 0.6$. (with cup-form bases in crowded individuals).

Fig. 7. Fossil B. (M.) rosa Pilsbry (UMUT-RA8206) from the Holocene Ohfuna shell bed (Loc. 25). $\times 0.9$. (with flat basis in an isolated individual on gravel).

\section{PLATE VII}

Figs. 1a-2b. Balanus (Megabalanus) volcano Pilsbry from Tôshima Is. (Loc. 5c). Photo by scanning electron microscope. 1a. left mandible, mv., $\times 29$, , 1b. ditto, $\times 58$., 2 a. right mandible, 1v., $\times 29 ., 2 b$. ditto, $\times 58$.

Figs. 3a-4b. Balanus (Megabalanus) rosa Pilsbry from Tanabe (Loc. $5 \mathrm{~m}$ ). Photo by scanning electron microscope. 3a. left mandible, mv., $\times 29$., 3b. ditto, $\times 45$., $4 a$. right mandible, 1v., $\times 29$., 4 b. ditto, $\times 45$. 


\section{PLATE VIII}

Fig. 1. Association of $B .(M$.$) volcano and B .(M$.$) rosa from Tosa Bay (Loc. 7). (UMUT-$ 8203). $\times 0.7 . \mathrm{v}:$ volcano, $\mathrm{r}:$ rosa, $\mathrm{t}:$ B. trigonus Darwin.

Figs. 2a-b. Association of $B$. (M.) volcano and $B$. (M.) rosa from Hosonoura (Loc. $5 \mathrm{~g}$ ). (UMUT-RA8204), $\times 0.8$. v: volcano, $\mathrm{r}$ : rosa.

Fig. 3. Mode of occurrence of fossil B. (M.) rosa of the Pleistocene Miyata formation (Loc. 26). (Allochthonous type).

Fig. 4. Mode of occurrence of fossil $B$. (M.) rosa of the Pleistocene Toshima sand (Loc. 28). (Authoch thonous type).

Fig. 5. Association of $B .(M$.$) volcano and B$. (M.) rosa on a cask for pearl culture at Hosonoura (Loc. $5 \mathrm{~g}$ ). v: zolcano, $\mathrm{r}$ : rosa.

Fig. 6. Association of $B$. (M.) volcano and B. (M.) rosa at pier of the Seto Marine Biological Laboratory (Loc. 5d). v: volcano, $\mathrm{r}$ : rosa. 
Publ. Seto Mar. Biol. Lab., XXI (2), 1973.

PLATE VI

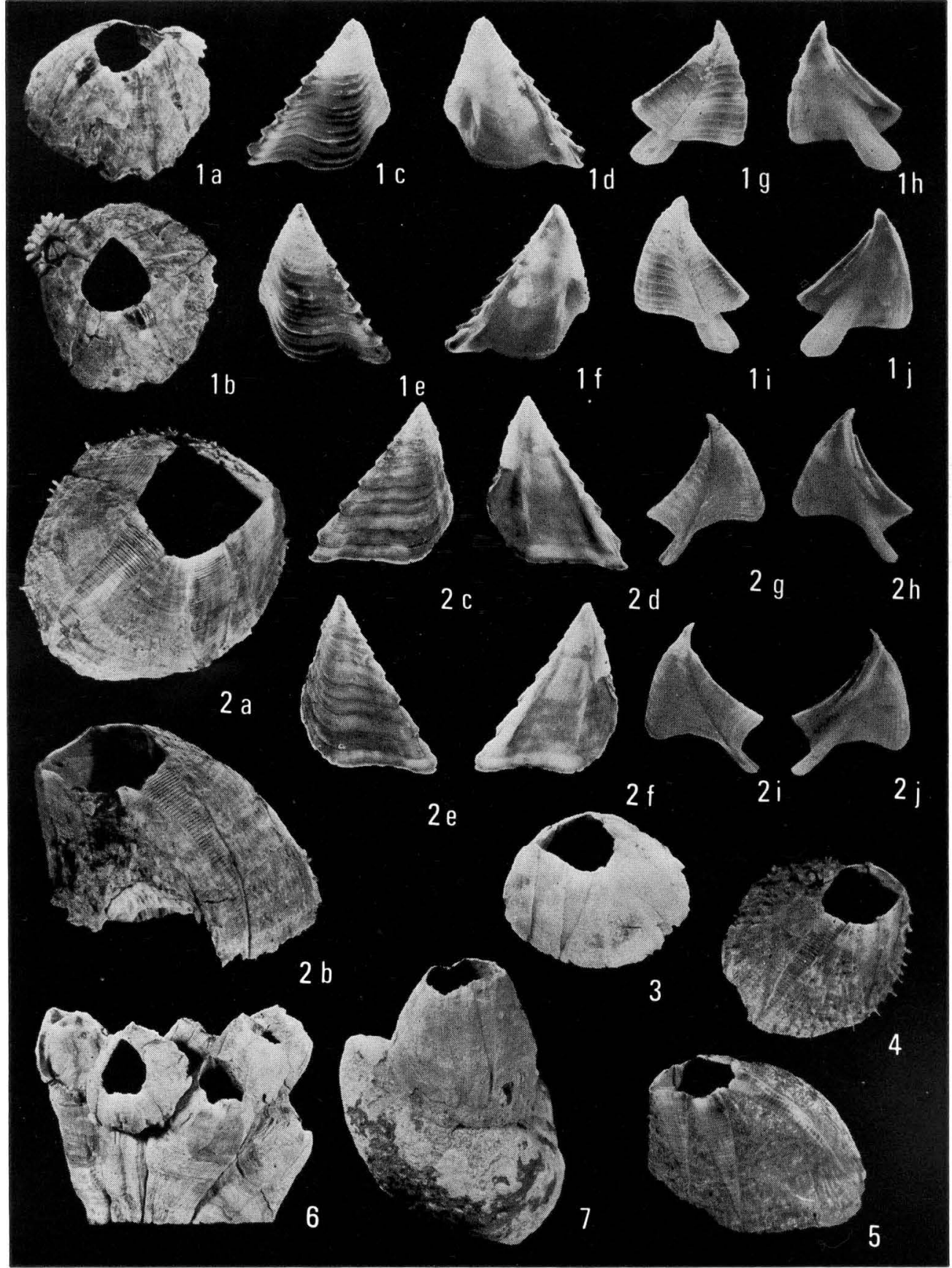

T. Yamagughi: On Megabalanus of Japan 
Publ. Seto Mar. Biol. Lab., XXI (2), 1973.
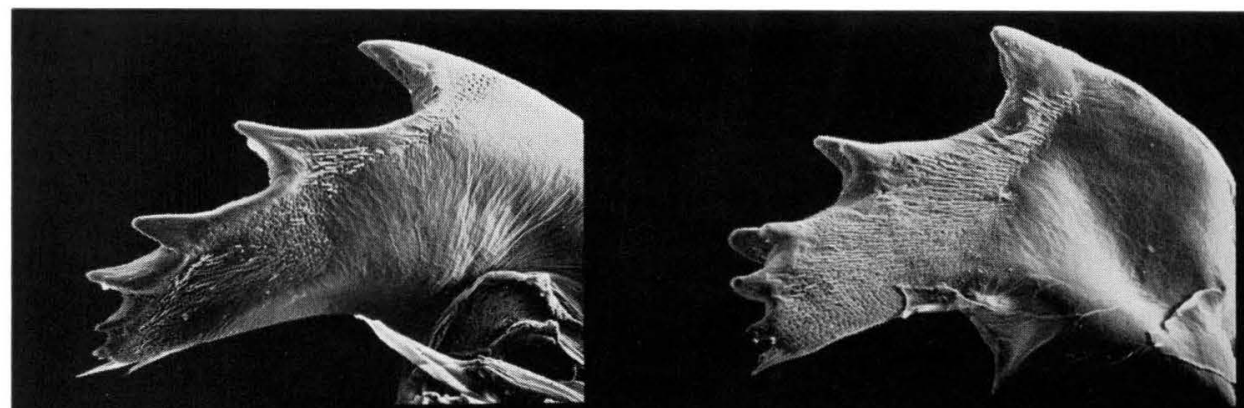

\section{1 a}

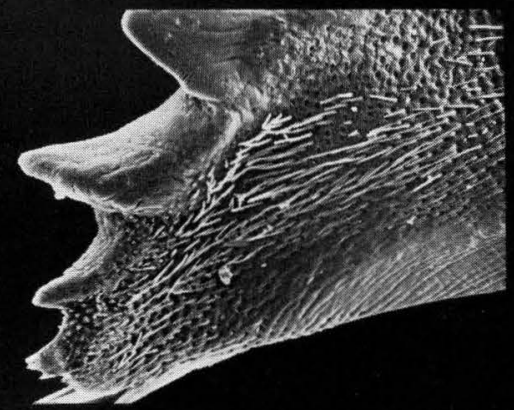

$1 \mathrm{~b}$

2 a
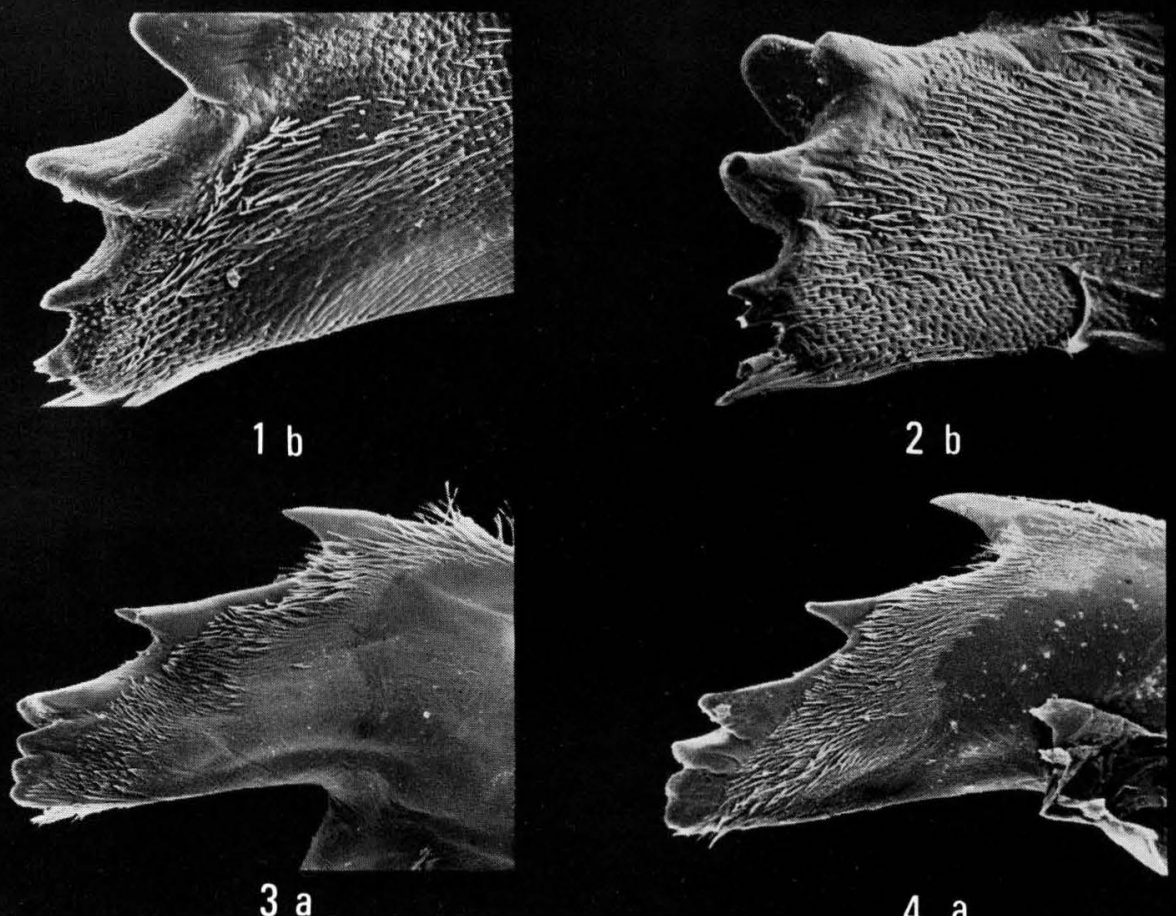

4 a
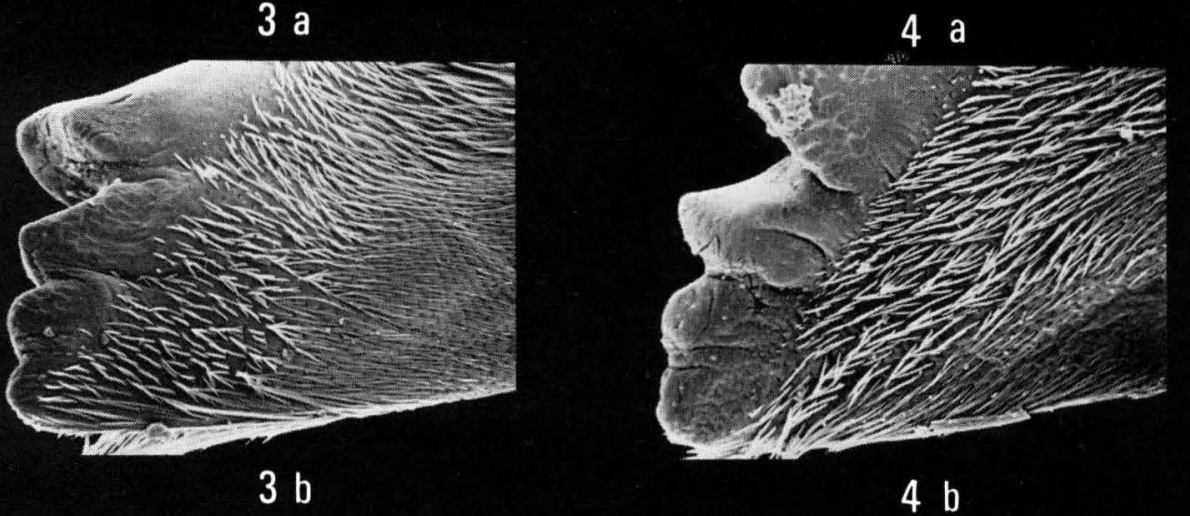

T. Yamaguchi: On Megabalanus of Japan 
Publ. Seto Mar. Biol. Lab., XXI (2), 1973.

PLATE VIII

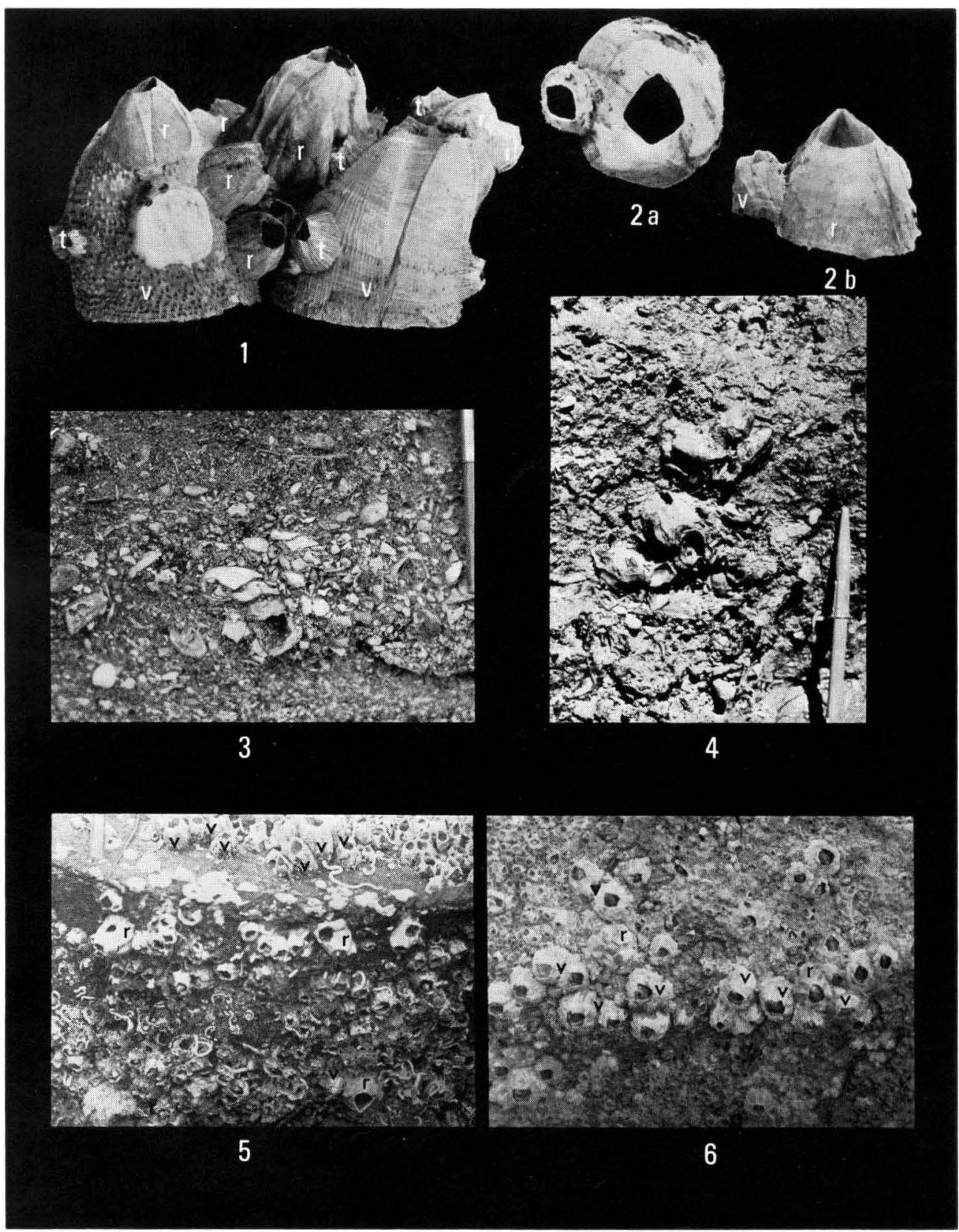

T. Yamagughi: On Megabalanus of Japan 